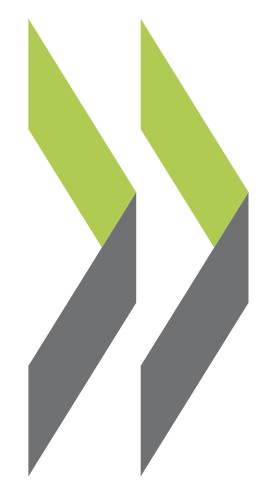

OECD Economics Department Working Papers No. 897

Austria: Public Sector Inefficiencies Have Become Less Affordable
Karin Fischer, Rauf Gönenç, Robert Price 
Organisation de Coopération et de Développement Économiques

Organisation for Economic Co-operation and Development

17-Oct-2011

ECONOMICS DEPARTMENT

English - Or. English

AUSTRIA: PUBLIC SECTOR INEFFICIENCIES HAVE BECOME LESS AFFORDABLE

ECONOMICS DEPARTMENT WORKING PAPERS No. 897

By Karin Fischer, Rauf Gönenç and Robert Price

All Economics Department Working Papers are available through the OECD internet website at www.oecd.org/WorkingPapers

JT03309271

Document complet disponible sur OLIS dans son format d'origine

Complete document available on OLIS in its original format 


\section{ABSTRACT/RESUMÉ}

\section{Austria: public sector inefficiencies have become less affordable}

Performance of fiscal policy, while good in international comparison, is not sufficient to prepare for future ageing-related spending increases. Subject to macroeconomic developments, the pace of consolidation could be more ambitious than currently planned, with a view to reducing the debt burden below $60 \%$ of GDP by 2020 . Austrian fiscal policies have tended to be pro-cyclical in upturns, mainly because spending was not adequately kept in check. Stronger fiscal rules and a reform of inter-governmental fiscal relations could help contain expenditure dynamics. Efficiency-raising reforms in key spending areas such as pensions and other social expenditures, health, and education are also highly needed to reduce spending and ensure the provision of high-quality public services at lower cost. In this regard, Austria should make full use of the performance budgeting framework it plans to introduce from 2013. Higher potential growth could also take off some of the pressure on public finances. There remains significant room to rebalance the tax structure towards less distortive sources of revenue, thus supporting employment and growth.

This Working Paper relates to the 2011 OECD Economic Survey of Austria (www.oecd.org/eco/surveys/austria)

JEL classification: E62, H68, $\mathrm{H} 77$.

Key words: Austria, federal, regional, budget, fiscal, deficit, debt, consolidation.

$* * * * * * * * * * * * * * * * * * * * * * * * * * * * * * * * * * * * * * * * * * * *$

\section{Autriche : Les carences du secteur public sont de moins en moins supportables}

Les résultats de la politique budgétaire menée par les autorités autrichiennes sont bons par rapport à d'autres pays, mais insuffisants pour faire face aux augmentations des dépenses qui seront induites par le vieillissement de la population dans les années à venir. En tenant compte des développements macroéconomiques, le rythme d'assainissement pourrait être plus rapide que ce n'est actuellement le cas, de façon à ramener la dette au-dessous de $60 \%$ du PIB d'ici 2020. Traditionnellement, la politique budgétaire en Autriche a toujours été procyclique au cours des phases ascendantes en raison d'une maîtrise insuffisante des dépenses. Le renforcement des règles budgétaires et la réforme des relations budgétaires entre administrations pourraient contribuer à endiguer la hausse des dépenses. De même, des réformes visant à accroître l'efficience des principales catégories de dépenses, comme les retraites et autres dépenses sociales, la santé et l'éducation sont indispensables pour freiner les dépenses et garantir des services publics de qualité à moindre coût. À cet égard, l'Autriche devrait recourir systématiquement au cadre de budgétisation dans l'optique des résultats qu'elle envisage de déployer en 2013. L'accélération d e la croissance potentielle pourrait également soulager les tensions qui s'exercent sur les finances publiques. Il reste encore beaucoup à faire pour rééquilibrer la structure de la fiscalité au profit des sources de recettes provoquant le moins de distorsions, afin de soutenir l'emploi et la croissance.

Ce Document de travail se rapporte à l'Etude économique de l'OCDE de l'Autriche 2011 (www.oecd.org/eco/etudes/autriche)

Classification JEL : E62, H68, $\mathrm{H} 77$.

Mots clés : Autriche, fédéral, régional, budget, fiscal, déficit, dette, consolidation.

Copyright OECD 2011.

Application for permission to reproduce or translate all, or part of, this material should be made to: Head of Publications Service, OECD, 2 rue André-Pascal, 75775 Paris CEDEX 16, France. 


\section{TABLE OF CONTENTS}

\begin{tabular}{|c|}
\hline ublic finances after the crisis.. \\
\hline Corrective action has begun............................................... \\
\hline 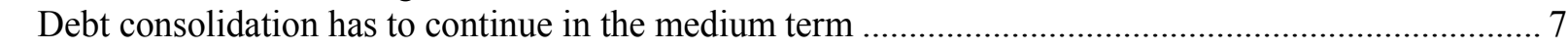 \\
\hline 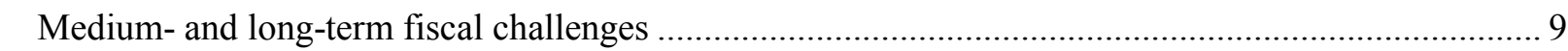 \\
\hline 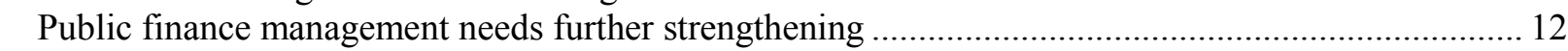 \\
\hline Public spending needs to be substantially restrained 16 \\
\hline Social protection spending should be better targeted \\
\hline Scope for efficiency gains needs to be identified sector-wise \\
\hline Progress with public sector reform is sluggish 19 \\
\hline Performance budgeting should help improve efficiency \\
\hline Towards a more growth-friendly tax structure \\
\hline Reforms should target low-income groups \\
\hline 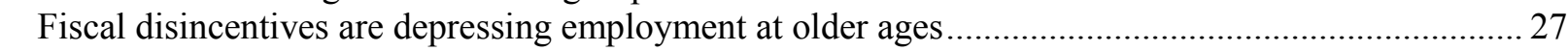 \\
\hline 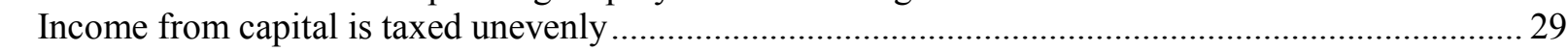 \\
\hline The property tax base is eroding \\
\hline
\end{tabular}

\section{Tables}

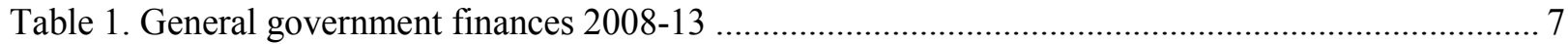

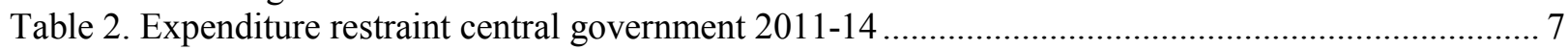

Table 3. Additional revenues general government 2011-14 ............................................................. 7

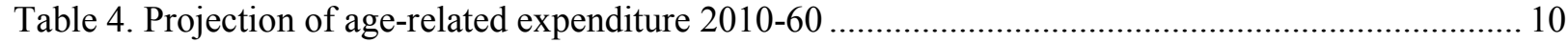

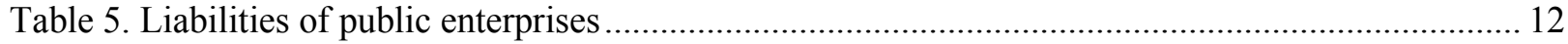

Table 6 Tax treatment of capital gains and interest deductibility for individuals ................................... 30

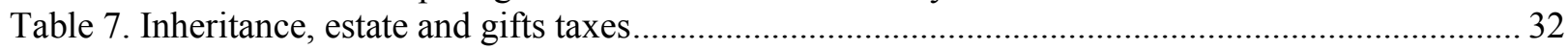

Disclaimer: This document and any map included herein are without prejudice to the status of or sovereignty over any territory, to the delimitation of international frontiers and boundaries and to the name of any territory, city or area. 


\section{Figures}

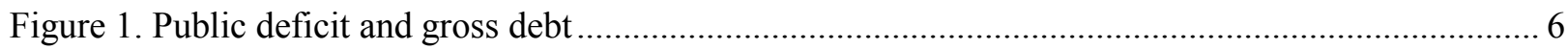

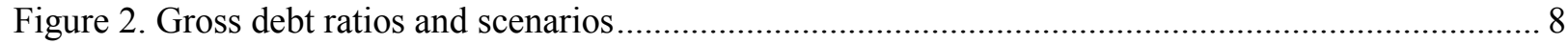

Figure 3. Interest rate differentials vis-à-vis Germany ......................................................................... 9

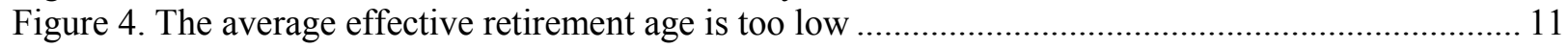

Figure 5. Public debt and deficit, investment and subsidies............................................................. 13

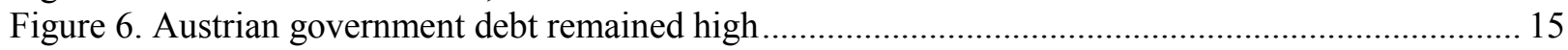

Figure 7. Austria is among the highest spenders on social programmes............................................. 17

Figure 8. The tax structure is biased towards distortive taxes on labour............................................. 21

Figure 9. Labour tax wedges are among the highest in the OECD ................................................... 22

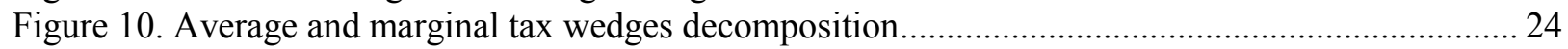

Figure 11. Average implicit tax on continued work at older ages......................................................... 27

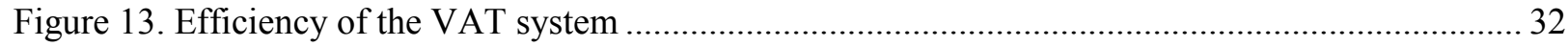

\section{Boxes}

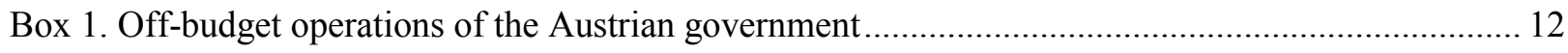

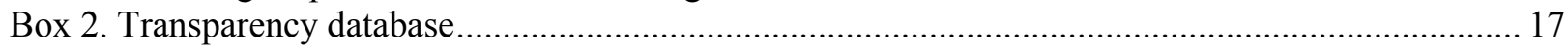

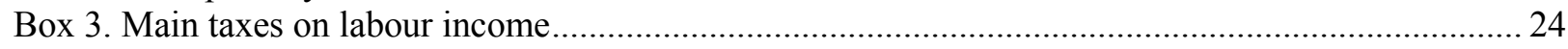

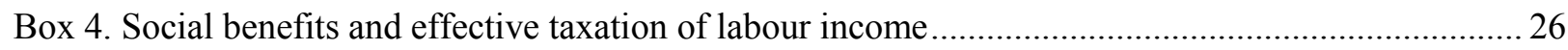

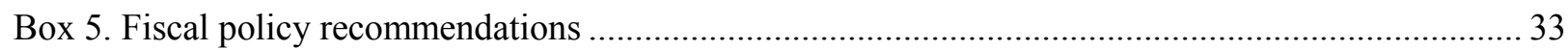


ECO/WKP(2011)66

\title{
AUSTRIA: PUBLIC SECTOR INEFFICIENCIES HAVE BECOME LESS AFFORDABLE
}

\author{
By Karin Fischer, Rauf Gönenç and Robert Price ${ }^{1}$
}

\section{Public finances after the crisis}

Austria's public finances worsened markedly in the course of the economic and financial crisis, with the deficit increasing from $0.9 \%$ of GDP in 2008 to $4.6 \%$ of GDP in 2010 . The deterioration was driven by discretionary stimulus measures - injected principally via cuts in personal income tax - and the operation of automatic stabilisers. The discretionary fiscal boost totalled 1.5\% of GDP in 2009 and $1.8 \%$ of GDP in 2010 and was largely in line with the European Economic Recovery Plan. Public debt rose from $63.8 \%$ of GDP in 2008 to $72.3 \%$ of GDP in 2010 and is set to increase further through to 2013. Part of the increase in the debt ratio (2.4 percentage points) is due to government support to the banking sector and bilateral loans to Greece. Support for Greece and other euro area countries (Ireland, Portugal) within the architecture of the European Financial Stability Facility (EFSF) will lead to further temporary increases in the debt ratio in the period 2011-13. Even so, Austria still compares favourably with the EU or OECD average.

The deterioration of the deficit and debt figures also reflects a comprehensive revision of government data in March 2011. A tightening of the criteria for private sector entities by Eurostat forced the re-incorporation of the deficit and debt of the Austrian railway company and public hospitals into government balance sheets. The public sector thus assumed additional debt of 2.2 percentage points of GDP in 2009 and a further 1.2 percentage points of GDP in 2010. Deficits turned out 0.6 percentage points and 1 percentage point higher in 2009 and 2010 respectively due to reclassifications. It is more transparent to account for such operations in the public sector, because repayment of these loans would have been unlikely without further public liquidity injections.

Nevertheless, budget shortfalls in Austria have largely been structural in nature. Fiscal policy used to be countercyclical during downturns but pro-cyclical or at best neutral during upturns (Brandner et al., 2009). For more than three and a half decades, budget deficits have been recorded irrespective of economic conditions, with the sole exception of the balanced budget in 2001. The last time the general government balance was in surplus was in 1974. Over the past three decades, the debt stock doubled from one third of GDP to more than two thirds. Interest expenditure on debt will consume almost 3\% of GDP or close to $6 \%$ of public expenditures in the years to come (Schratzenstaller, 2010). The expected normalisation of interest rates would gradually drive up debt servicing costs.

1. Karin Fischer is from Austria's Ministry of Finance and was seconded to OECD for the preparation of the 2011 Economic Survey of Austria. Rauf Gönenç is Head of Austria Desk, OECD. Robert Price has been a consultant for this project. This Working Paper has been published as Chapter 1 of the OECD's 2011 Economic Survey of Austria (www.oecd.org/eco/surveys/austria). The authors are grateful for the important contributions received from OECD colleagues Andrew Dean, Robert Ford, Andreas Wörgötter, Oliver Röhn and Béatrice Guérard; from officials from the Austrian Ministry of Finance; and from researchers of the Institute of Economic Research (WIFO) and the Institute for Advanced Studies (IHS) in Vienna, including Alfred Katterl, Eduard Fleischmann, Bernhard Felderer, Margit Schratzenstaller, and Karin Schönpflug. 
Figure 1. Public deficit and gross debt

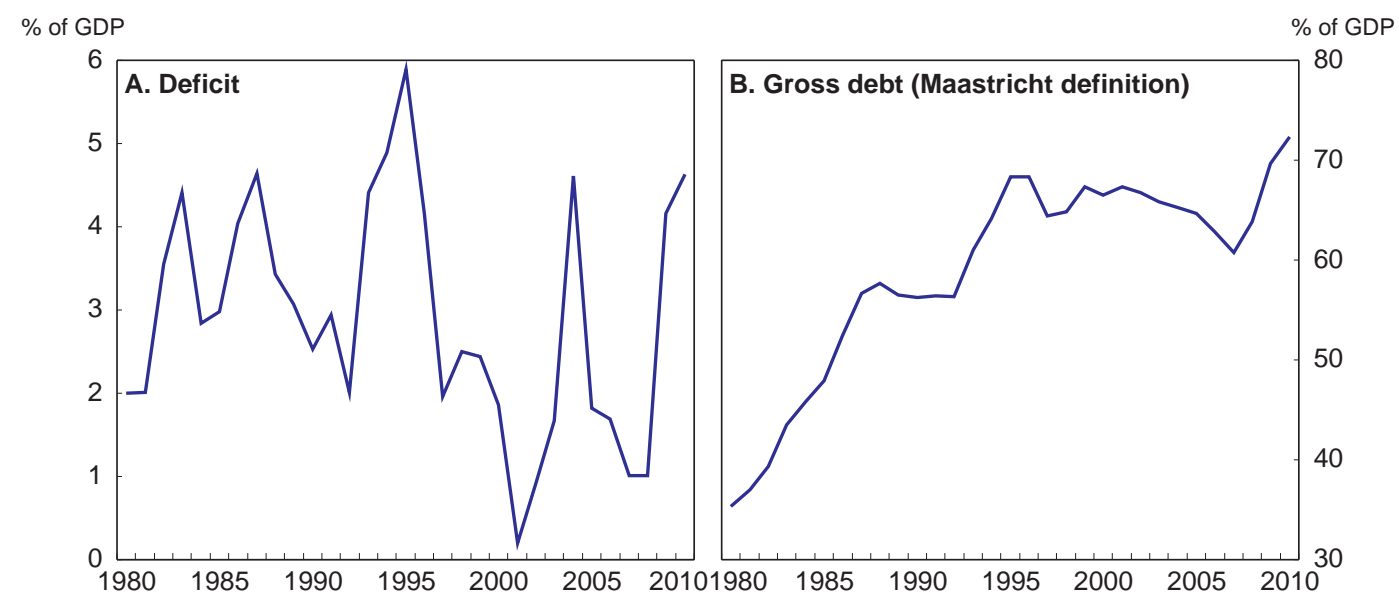

Source: OECD Economic Outlook Database for public deficit and Statistics Austria for gross debt.

\section{Corrective action has begun}

As the recovery takes hold, a comprehensive strategy is needed to reverse the increase in the deficit and debt ratio so as to regain budgetary room for manoeuvre and cope with emerging medium- and long-term challenges. High and rising debt burdens risk exposing countries to financial market volatilities, as bond markets have become increasingly wary about governments' ability to address unsustainable fiscal positions. Inadequate consolidation efforts may thus trigger interest rate hikes and a country may quickly find itself in an uncomfortable position. Empirical evidence also suggests that a high level of public debt may hamper long-term growth through the negative impact of higher interest rates on business investment. A debt level of above $90 \%$ of GDP has been found to reduce growth by about 1 percentage point per year (Reinhart and Rogoff, 2010).

On 2 December 2009 the Council of the European Union adopted a decision stating that Austria had an excessive deficit and recommended correction by 2013, with consolidation starting in 2011 and improving the structural balance by $3 / 4$ percentage points of GDP per year. In the event, the Austrian authorities have specified measures in the 2011 Budget which should permit the deficit to fall below $3 \%$ of GDP by 2013 (see Tables 1-3). The main measures on the expenditure side are cuts in social spending (family and long-term care benefits), administrative costs, and subsidies and transfers, as well as restraints on pensions. Savings are also expected in the area of interest payments on government debt. ${ }^{2}$ Measures on the revenue side include a "stability levy" on banks, an increase in fuel taxation, a flight ticket tax, an increase in tobacco taxes and changes in the taxation of capital gains and foundations (introduction of a withholding tax on financial assets). Moreover, policies to combat fraud are expected to generate additional revenues. Measures on the expenditure side account for nearly $60 \%$ of the total consolidation volume and are borne by the central government. The state and municipal levels benefit from new tax revenues and are embedded in the national consolidation strategy via the Domestic Stability Pact, which allows Länder (state governments) a deficit of $0.75 \%$ of GDP in 2011, $0.6 \%$ in 2012, and $0.5 \%$ in 2013-14, while municipalities are required to record balanced budgets.

2. The assumption is that interest payments decrease as a result of a smaller debt stock compared to a "no policy change" scenario. 
In addition to the measures in the 2011 Budget, the Medium-term Budgetary Framework Law 2012-15 of April 2011 specified a path for nominal central government expenditure growth at $1.8 \%$ of GDP on average per year. Under the assumption of nominal GDP growth of $4 \%$ per year and an unchanged revenue ratio, this is expected by the government to gradually reduce the expenditure ratio and bring down the fiscal deficit to $2 \%$ of GDP by 2015.

Table 1. General government finances 2008-13

\begin{tabular}{lcccccc}
\hline \multicolumn{1}{c}{ \% of GDP } & 2008 & 2009 & 2010 & 2011 & 2012 & 2013 \\
\hline General government balance & -0.9 & -4.1 & -4.6 & -3.9 & -3.3 & -2.9 \\
Structural balance & -1.8 & -2.6 & -3.2 & -2.8 & -2.4 & -2.1 \\
Total disbursements & 49.3 & 53.0 & 53.0 & 52.2 & 51.6 & 51.0 \\
Total receipts & 48.3 & 48.8 & 48.3 & 48.3 & 48.2 & 48.2 \\
Gross public debt (Maastricht) & 63.8 & 69.6 & 72.3 & 73.6 & 75.0 & 75.5 \\
\hline
\end{tabular}

Source: Statistics Austria; Federal Ministry of Finance, 2011a (figures for 2011-13 according to government plans).

Table 2. Expenditure restraint central government 2011-14

\begin{tabular}{lrrrr}
\hline \multicolumn{1}{c}{ EUR million } & $\mathbf{2 0 1 1}$ & $\mathbf{2 0 1 2}$ & $\mathbf{2 0 1 3}$ & $\mathbf{2 0 1 4}$ \\
\hline Social expenditures & -734 & -860 & -970 & -1093 \\
Pensions & -356 & -400 & -469 & -549 \\
Transfers to families & -246 & -278 & -278 & -278 \\
Others & -132 & -182 & -223 & -266 \\
Administration costs & -486 & -791 & -868 & -963 \\
Subsidies and transfers & -190 & -330 & -404 & -458 \\
Interest payments & -86 & -229 & -454 & -712 \\
& $-\mathbf{1 4 9 6}$ & $\mathbf{- 2} \mathbf{2 1 0}$ & $\mathbf{- 2} \mathbf{6 9 6}$ & $\mathbf{- 3 2 2 6}$ \\
\hline
\end{tabular}

Source: Federal Ministry of Finance, 2011a.

Table 3. Additional revenues general government 2011-14

\begin{tabular}{lrrrr}
\hline \multicolumn{1}{c}{ EUR million } & $\mathbf{2 0 1 1}$ & $\mathbf{2 0 1 2}$ & $\mathbf{2 0 1 3}$ & $\mathbf{2 0 1 4}$ \\
\hline Stability levy on banks & 500 & 500 & 500 & 500 \\
Fuel tax & 417 & 470 & 470 & 470 \\
Anti-fraud package & 100 & 200 & 300 & 400 \\
Capital gains tax & 30 & 50 & 100 & 250 \\
Tobacco tax & 100 & 150 & 150 & 150 \\
Corporate tax & 0 & 200 & 200 & 200 \\
Others & 17 & 171 & 201 & 221 \\
& $\mathbf{1 1 6 4}$ & $\mathbf{1 7 4 1}$ & $\mathbf{1 9 2 1}$ & $\mathbf{2 1 9 1}$ \\
\hline
\end{tabular}

Source: Federal Ministry of Finance, 2011a.

\section{Debt consolidation has to continue in the medium term}

The pace of consolidation could be more ambitious, the timing of consolidation would be subject to evolving macroeconomic conditions, with a view to reducing the debt burden to sustainable levels and accommodating future fiscal pressures. Under the current medium-term fiscal consolidation plan, the budget deficit will decrease to $2 \%$ of GDP by 2015 . However, without a further improvement in the budget stance, this would not be sufficient to bring down debt rapidly enough. Extrapolating the deficit of $2 \%$ in 
2015 through to 2020 and assuming a constant nominal growth rate of $3.7 \%$ after 2012, the debt-to-GDP ratio would remain above pre-crisis levels until 2020 (Figure 2, Panel B). By contrast, an immediate, ambitious and front-loaded consolidation programme, which aims at reducing the deficit to $1 \%$ of GDP in 2013 and $0.5 \%$ in 2014, similar to the German debt brake, and leaving the deficit at this level thereafter, would reduce the debt-to-GDP ratio below $60 \%$ by 2020 . A medium-term ambitious consolidation scenario, foreseeing a further decline in the deficit by 0.5 percentage point of GDP after 2015 until a balance of $-0.5 \%$ of GDP is reached, would not bring down the debt-to-GDP ratio below $60 \%$ until 2020 .

Figure 2. Gross debt ratios and scenarios
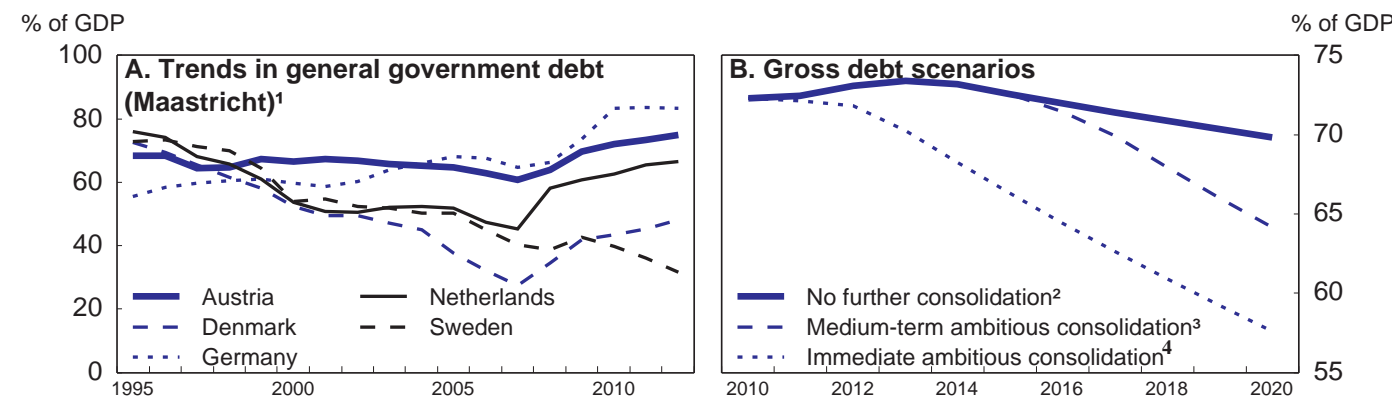

1. Data after 2010 are projections.

2. Nominal GDP growth of $4.7 \%$ in 2011 and $3.7 \%$ thereafter, and a budget deficit of $3.7 \%$ of GDP in 2011 with a gradual reduction to $2 \%$ of GDP by 2015 and no further consolidation thereafter is assumed.

3. Same assumptions as in (2), but further consolidation of 0.5 percentage point is assumed after 2015 until a budget deficit of $0.5 \%$ is reached.

4. Same nominal GDP growth assumptions as in (2) and (3), but the deficit is gradually reduced from $4.6 \%$ of GDP in 2010 to $0.5 \%$ of GDP by 2014 and held constant thereafter.

Source: OECD, OECD Economic Outlook database; OECD calculations based on data from OECD Economic Outlook

The fiscal position is vulnerable to higher interest rates, which have been relatively low for some time. Higher interest rates would raise debt-servicing costs and thereby increase pressure to cut non-interest spending to reach the deficit target. The eventual normalisation of financial conditions and policy rates is likely to involve a general increase in long-term interest rates. In addition, an increase in the debt-to-GDP ratio could translate into a larger premium on Austrian sovereign debt, which is now relatively small, at 40 basis points over German rates. The threshold at which Austrian risk premia could begin to rise cannot be predicted with certainty. ${ }^{3}$ However, the risk that high and rising government debt may add upward pressure on long-term government bond yields and depress growth should be factored into budget planning.

3. There is tentative evidence that when gross government indebtedness passes a threshold of $75 \%$ of GDP long-term interest rates increase (decrease) by 4 basis points for every additional percentage point increase (decrease) in the government debt-to-GDP ratio (OECD, 2010d). 
Figure 3. Interest rate differentials vis-à-vis Germany

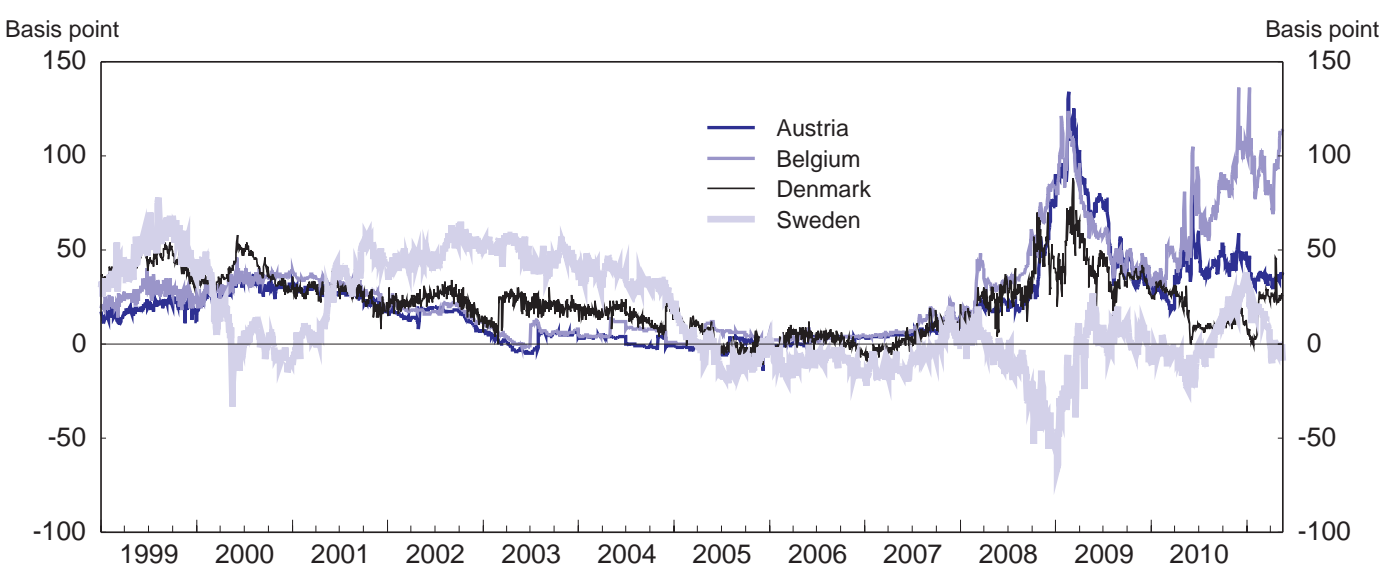

Note: The interest rate differentials vis-à-vis Germany are based on 10-year government benchmark bonds; latest available data as of 18 May 2011.

Source: Datastream.

\section{Medium- and long-term fiscal challenges}

A reduction of the current debt-to-GDP ratio is all the more important as future spending pressures increase. A forward-looking assessment of public finances must consider implicit liabilities of the public sector not reflected in government deficit and debt figures. These are commitments to the public pension scheme and loan guarantees to infrastructure companies ${ }^{4}$, the banking sector or other euro area countries under the EFSF. The latter are contingent liabilities, i.e. costs the government would have to incur in the event of a borrower's default. The probability of such an event is uncertain, but its impact on public finances would nevertheless be significant.

\section{Population ageing adds considerable pressure to public finances}

Austria's population is projected to age rapidly. The number of elderly persons aged 65 or above will increase markedly, while the working-age population between 15 and 64 will decline as from 2020 onwards. The European Commission (2009) projects the old-age dependency ratio (i.e. the ratio of people aged 65 or more to the population aged 15-64) to double from $25 \%$ in 2008 to $51 \%$ in 2060 . Austria would thus move from having 4 persons of working-age for every person aged over 65 to a ratio of only 2 to 1 . The largest shift in the old-age dependency ratio is expected to occur in the period between 2020 and 2030, and costs for the public sector will be highest between 2040 and 2050.

Demographic developments will put considerable strain on public finances. Based on projections by the European Commission (2009), the government expects that population ageing will add an extra 3.1 percentage points of GDP to public spending in the period up to 2060 (Table 4). Most of the projected increase is due to higher costs for health care, followed by rising expenditure on long-term care, and then pensions. The projected increase in age-related expenditure is less than in other EU countries, but Austria's starting position is higher as it currently spends an above-average share on pensions and health and

4. The reclassification decision of March 2011 moved only a comparatively small part of the debt of public enterprises back on government accounts, so that the bulk of liabilities incurred by public service providers remains off-budget. However, the reclassification covered a substantial part of the deficit of off-budgetentities between the years 2007-10. 
long-term care (13.5\% of GDP and $8.5 \%$ of GDP respectively). According to the European Commission (2009), Austria is a "medium risk" country in terms of sustainability of public finances under the pressures of population ageing.

Table 4. Projection of age-related expenditure 2010-60

\begin{tabular}{lcccccc}
\hline \multicolumn{1}{c}{ \% of GDP } & $\mathbf{2 0 1 0}$ & $\mathbf{2 0 2 0}$ & $\mathbf{2 0 3 0}$ & $\mathbf{2 0 4 0}$ & $\mathbf{2 0 5 0}$ & $\mathbf{2 0 6 0}$ \\
\hline Age-related expenditure & 27.6 & 27.8 & 29.4 & 30.2 & 31.0 & 30.7 \\
Pensions & 13.6 & 13.7 & 14.5 & 14.6 & 14.7 & 14.3 \\
Health care & 7.1 & 7.5 & 7.9 & 8.3 & 8.6 & 8.5 \\
Long-term care & 1.4 & 1.5 & 1.8 & 2.1 & 2.5 & 2.6 \\
Education & 4.8 & 4.4 & 4.5 & 4.5 & 4.5 & 4.6 \\
\hline
\end{tabular}

Source: Federal Ministry of Finance (2011a), update of European Commission 2009.

However, these projections involve risks, particularly with regard to pension expenditures. They assume that average pensions relative to wages fall markedly over the projection horizon, even though over the past few years, average pensions grew more than average wages. ${ }^{6}$ It is also assumed that people will retire later in the future. Some progress in this area has been made recently, but the retirement age remains very low. Austrian male workers exit the labour market at age 59 on average and females at age 57, the second lowest in the OECD after Luxembourg (Figure 4). Strong financial disincentives to continue work at older ages have kept the effective retirement age in Austria low (see below). According to a recent report by the OECD (2011, pp. 44-46), if only demographic changes as the main driver of pension expenditures are considered, pension expenditures would rise by more than 9 percentage points by 2060 to $23 \%$ of GDP - one of the highest shares in the OECD. ${ }^{7}$ This implies that significant efforts are needed if pension expenditures are to be contained.

5. The "sustainability gap" measures the size of the budgetary adjustment required to ensure that the $60 \%$ threshold for the debt-to-GDP ratio as prescribed by the Maastricht Treaty is reached by 2060. Based on the budgetary position for 2009, the required adjustment of the primary balance has been calculated at 3.8 percentage points of GDP. Under the assumption of a favourable initial position (i.e. budget balance and the debt-to-GDP ratio in line with the $3 \%$ of GDP/ $60 \%$ of GDP thresholds according to the Stability and Growth Pact), an improvement in the primary balance in the order of 2.2 percentage points of GDP is needed to cope with the fiscal cost of population ageing as estimated by the European Commission.

6. The decreasing path of this ratio is foreseen by enacted legislation (e.g. through the on-going shift of employees from the civil service scheme to the private sector insurance scheme, through the extension of the assessment period, which is phased in gradually by 2028, and through the introduction of individual pension accounts, which are also subject to a phase-in period due to parallel accounting with the old schemes).

7. Already enacted legislation, if fully implemented, is expected to decrease the generosity of the system and raise the effective retirement age. Along with increasing participation rates, this should mitigate the rise in pension expenditures. 
Figure 4. The average effective retirement age is too low
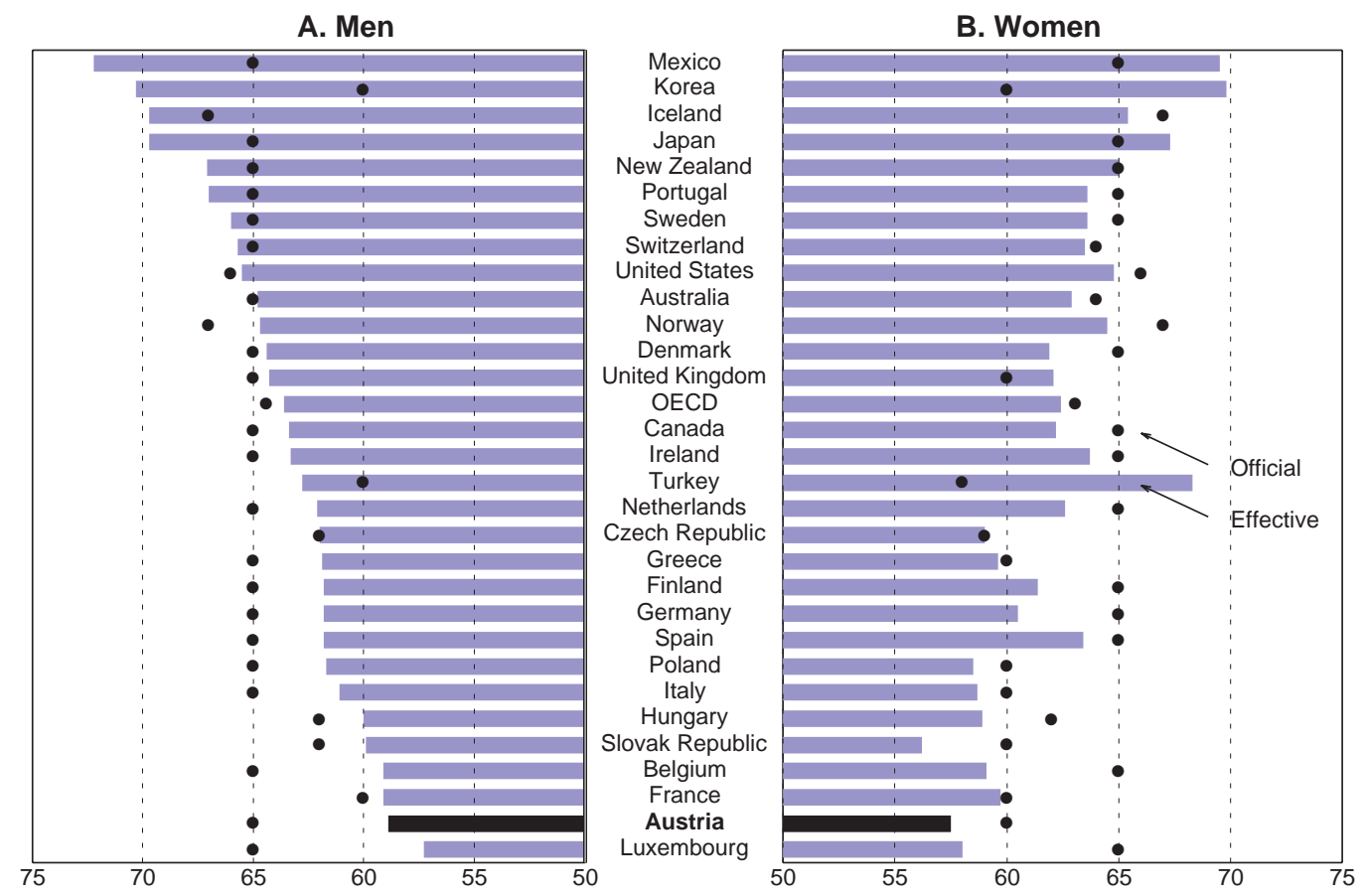

Note: Effective retirement age shown is for five-year period 2004-09; pensionable age is shown for 2010.

Source: OECD, Pensions at a Glance 2011: Retirement-Income Systems In OECD and G20 Countries, Figure 2.3, p. 43.

Projections of health and long-term care costs are also subject to large uncertainties, mainly because of non-demographic factors such as developments in health technology and rising relative prices of health and long-term care. According to evaluations in the 2011 OECD Economic Survey of Austria, cost increases may be more than 4 percentage points higher up to 2030 .

\section{Off-budget liabilities may influence fiscal outcomes in the medium-term}

Public enterprises reported EUR 27.5 billion in outstanding debt in 2010 (9.6\% of GDP), with more than half of it accounted for by the Austrian railway company and another significant share by the road company/ASFINAG (see Table 5). These liabilities are estimated to increase further in 2011. In addition, there are debts accrued by off-budget entities such as infrastructure companies at municipal level, amounting to about EUR 12.6 billion in 2010 (4.4\% of GDP) (Federal Ministry of Finance; Government Debt Committee, 2010). Guarantees to the banking sector and other euro area member states have risen considerably in the course of the crisis. Most relevant are federal guarantees to commercial banks, which reached EUR 29 billion in 2009 (Aiginger et al., 2010). Moreover, guarantees of some state governments, such as Kärnten's guarantee for the bank group Hypo Alpe Adria AG, reached significant amounts, but are expected to diminish gradually and expire in 2017 at the latest. 
Table 5. Liabilities of public enterprises

\begin{tabular}{|c|c|c|c|c|c|c|}
\hline EUR billion & 2005 & 2006 & 2007 & 2008 & 2009 & 2010 \\
\hline \multicolumn{7}{|l|}{ Federal level } \\
\hline Austrian railway company & 5.8 & 7.1 & 9.3 & 11.1 & 12.5 & 14.4 \\
\hline Road company/ASFINAG & 9.3 & 8.6 & 9.2 & 8.4 & 8.8 & 10.0 \\
\hline Federal facility management company & 3.3 & 3.3 & 3.3 & 3.1 & 2.7 & 3.0 \\
\hline \multirow[t]{2}{*}{ Others } & 0.6 & 0.3 & 0.2 & 0.1 & 0.1 & 0.1 \\
\hline & 19.0 & 19.3 & 22.0 & 22.7 & 24.1 & 27.5 \\
\hline of which included in government debt & 4.1 & 3.5 & 3.6 & 4.4 & 5.0 & 6.0 \\
\hline \multicolumn{7}{|l|}{ States } \\
\hline Hospitals & 0.6 & 0.8 & 1.0 & 1.3 & 2.2 & 2.9 \\
\hline of which included in government debt & 0.6 & 0.8 & 1.0 & 1.3 & 2.2 & 2.9 \\
\hline \multicolumn{7}{|l|}{ Municipalities } \\
\hline Communal infrastructure companies & 11.7 & 12.1 & 12.2 & 12.5 & 12.5 & 12.6 \\
\hline Total & 31.3 & 32.2 & 35.2 & 36.5 & 38.8 & 43.0 \\
\hline of which included in government debt & 4.7 & 4.3 & 4.6 & 5.7 & 7.2 & 8.9 \\
\hline
\end{tabular}

Source: Federal Ministry of Finance.

\section{Public finance management needs further strengthening}

The institutional background for budgetary planning has improved with the introduction of a 4-year fiscal framework as part of a comprehensive budget law reform. Since 2009, legally binding expenditure ceilings have been in place for five main expenditure categories, covering about $75 \%$ of central government outlays. The new budgetary framework also created saving incentives for line ministries by allowing the carry-over of unspent funds from one year to the next. Some flexibility in central government spending is allowed for business cycle-sensitive areas, with variable ceilings that oscillate around defined parameters to ensure the working of automatic stabilisers. Other applications of variable ceilings are expenditure related to reimbursement from the EU, expenditure directly related to revenue (e.g. shares of value-added tax for hospital financing), and expenditure for guarantees (Steger, 2010).

Preliminary experience with the new expenditure framework is good and raises the credibility of the central government's budget plans. In particular, the ceilings exerted discipline over spending and the carry-over of unused funds successfully avoided "December fever". Line ministries were cautious about committing all available resources and built considerable reserves. As a result, in 2011, they have about EUR 1.4 billion in addition to their budgetary appropriations, which they can use to finance special projects not foreseen at the time the expenditure framework was passed. It remains, however, to be seen whether the possibility to carry forward reserves will lead to a macroeconomically relevant loss of control over effective fiscal performance.

\section{Box 1. Off-budget operations of the Austrian government}

In the run-up to monetary union, many EU countries used one-off measures and "creative accounting" to bring general government deficit and debt figures in line with the Maastricht ceiling of $3 \%$ of GDP and 60\% of GDP respectively. Examples are corporatisation of hitherto public entities such as hospitals and infrastructure providers, sale and lease-back operations, classification of capital injections into public enterprises as financial transactions instead of capital transfers, above-the-line treatment of privatisation operations, and changes in the calendar for tax payments. More stringent fiscal rules and decentralised budgets have been found to make recourse to such operations more likely (Koen and Van den Noord, 2005).

Austria employed this type of procedures mainly in the form of reclassification from the public to the private sector. For example, the road company/ASFINAG, founded in 1982, was restructured in 1997. Besides, hospitals in four states and communal infrastructure providers were moved off-budget. Reclassification operations were estimated 
to have improved the budget balance by $0.5 \%$ of GDP and the debt ratio by $5.2 \%$ of GDP in the period $1996-97$ (Schratzenstaller, 2010, p. 155). A second wave took place in the early 2000 s, when the federal facility management company expanded its business and hospital providers in the other five states were moved off-budget. At the same time, there was a change in hospital financing, with some state governments resorting to granting loans rather than injecting capital, thereby reducing deficits. These measures are estimated to have improved the budget balance by about $0.5 \%$ a year over the period 2001-04 (ibid.). In 2006, however, Statistics Austria decided that the new accounting practice with regard to hospital financing is not in line with ESA accounting principles and retroactively revised deficit figures accordingly.

Reclassification does not per se improve fiscal sustainability. In contrast to privatisation, the government retains influence in some form or other on the entity and thus carries operational risk. If the government incurs implicit liabilities for the debt of reclassified units and continues to finance their deficits, this is a pure accounting operation and the true public finance position remains unaffected. However, the information value of common fiscal indicators can be reduced considerably, as proceeds, costs and accumulated liabilities vanish from government balance sheets. The debt ratio in particular may lose significance as an indicator of long-term sustainability when there are sizeable off-budget liabilities (Prammer, 2009).

The long-term impact of reclassification on government finances has to be assessed against the viability of the entities concerned. Austria is one of the countries in the OECD with the highest share of government subsidies and transfers to business, amounting to above 5\% of GDP. More than half of this money goes to public enterprises outside the government sector and to hospitals. Even excluding for the purpose of international comparison the share allocated to health care units (1.5\% of GDP in 2008), transfers to businesses and public entities remain well above the level in other countries (4\% of GDP as compared to $2.3 \%$ of GDP in the OECD; data for 2008). On the other hand, government investment has come down significantly, from more than $3 \%$ of GDP in the early 1990 s to a low of $1.1 \%$ of GDP in 2008 (as compared to $3.3 \%$ in the OECD), as most investment is now carried out by firms outside the government sector (Prammer, 2009; Pitlik et al., 2010).

There is also a risk that hitherto implicit liabilities could re-enter public balance sheets as explicit liabilities, as has already happened to some extent in March 2011. One of the criteria for qualification as a "market producer" under the European System of Accounts (ESA 95) is that sales cover more than $50 \%$ of production costs. Discussions for tightening the criteria are currently underway, and chances are that some reclassified units in Austria no longer meet the requirements. The Austrian railways, for example, receives more than a third of sales revenues from the government in the form of compensation for infrastructure maintenance, social pricing and environmental measures. The facility management company could also be affected by more restrictive criteria and be forced back on government balance sheets.

Figure 5. Public debt and deficit, investment and subsidies

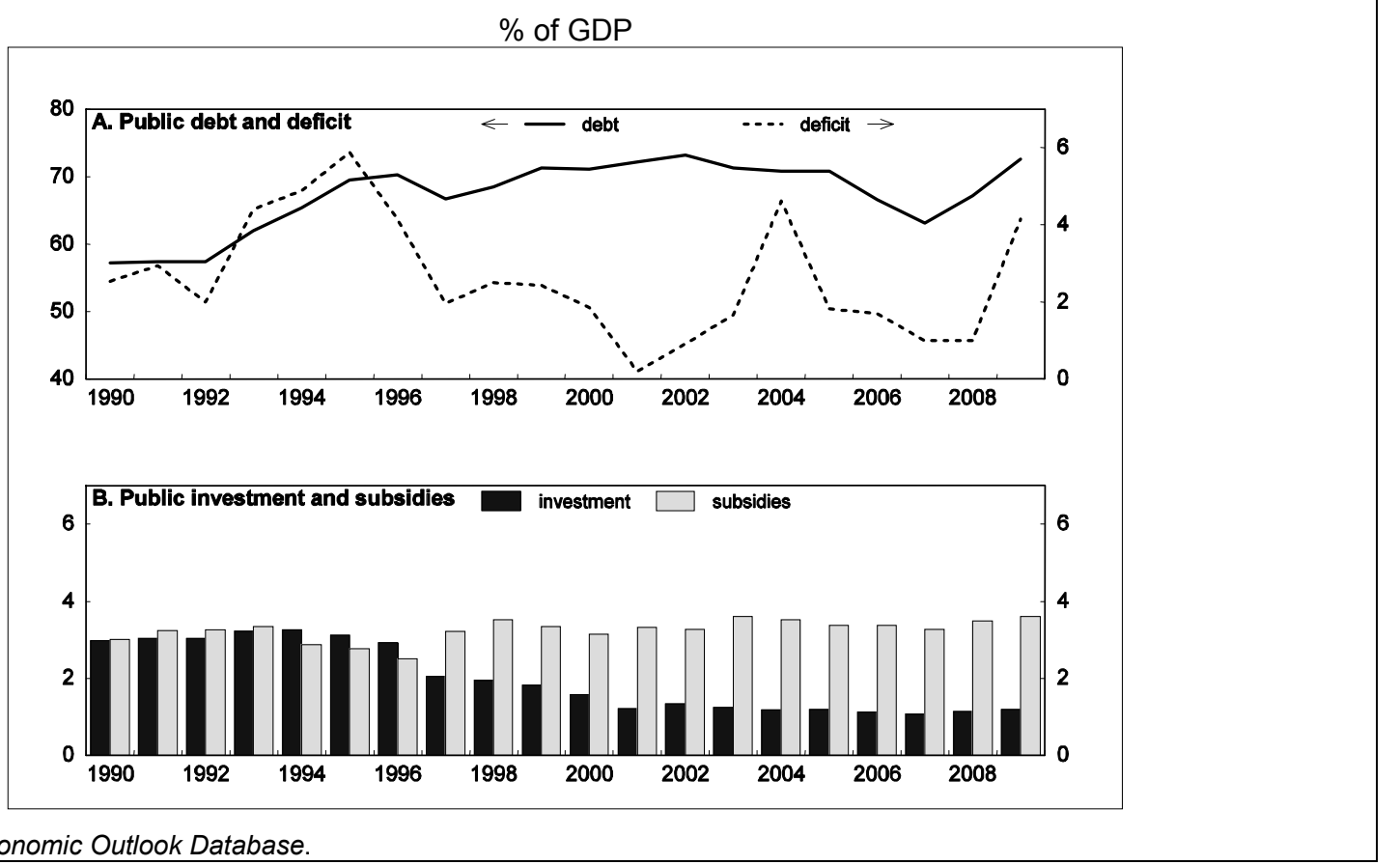


However, the expenditure framework covers only about $40 \%$ of total general government outlays. Sub-central governments have so far resisted the implementation of the budget law reform, and social security funds are also not subject to the ceilings. Thus the risk of expenditure overruns has not yet been fully contained.

\section{Fiscal federal relations continue to hamper consolidation}

Fiscal relations between the three layers of government - the central government, the states, and the municipalities- are characterised by fragmented taxing and spending powers. Sub-federal governments spend almost one third of total outlays but have only limited tax competences, to some extent because of own decisions. Resources are assigned to them via transfers, co-financing and shared taxes, based on a weighted population key and with a view to reducing inequalities among regions.

Two instruments are in place to govern fiscal relations: the Domestic Stability Pact and the Fiscal Equalisation Act. While the former sets annual deficit targets for the three levels of government, the latter determines the allocation of revenues between them. Both are renegotiated periodically, usually in connection with each other. The current arrangements were agreed in early 2011 and are in place until 2014. States are required to gradually reduce their deficits from $0.75 \%$ of GDP in 2011 to $0.5 \%$ of GDP in 2013 and 2014, while municipalities have to achieve balanced budgets. The central government is responsible for ensuring that general government deficit targets as set out in the Stability Programme are met.

There are no limits to the debt ratio in the Domestic Stability Pact, but all administrative levels committed to set ceilings for liabilities (e.g. guarantees to banks, public enterprises or hospital operating companies) and they are now also obliged to report newly created off-budget entities to the national statistical agency, thus increasing transparency. However, the effectiveness of the guarantee ceilings remains to be seen, in particular because their level can be decided autonomously by individual governments. Nevertheless, this marks progress, because the hitherto exclusive focus on the deficit had encouraged states and municipalities to move spending off their books, thus reducing the integrity of fiscal indicators without necessarily improving fiscal positions.

Sanctioning mechanisms in the case of non-compliance with deficit targets have been reinforced recently. Since the first Domestic Stability Pact was adopted, some states have consistently failed to adhere to the budgetary targets. Fines would have been possible in theory but no attempt has ever been made to apply them, because the set-up of the sanctioning mechanism (unanimous agreement to start an internal excessive deficit procedure, including by the state that breached the deficit target) rendered it a mere hypothetical tool. New arrangements will make the Domestic Stability Pact a more effective instrument to address the risk of budget shortfalls at sub-central levels of government:

- In case of negative deviations from deficit targets, if the violation of the deficit target is confirmed by an ex officio report of the Court of Audit, an arbitration committee will be installed. The committee consists of representatives of the central government and the administrative level concerned (the "peers"), but the state or municipalities in breach of the deficit target have no say.

- Agreements can now also be reached in the absence of one of the negotiating parties. If the committee decides that the Domestic Stability Pact was violated, the state or municipality concerned is demanded a deposit equal to $15 \%$ of the deficit overrun. The deposit will be returned if the overrun is corrected within the next fiscal year, but is lost in case of repeated failure to adhere to the budgetary targets. 
Despite these improvements, pro-cyclical elements in the design of inter-governmental fiscal relations remain a problem. Sub-federal governments receive a constant proportion of mostly cyclically sensitive tax revenues such as personal income tax, corporate tax, and value added tax, while their deficit targets are fixed as a percentage of GDP for a 4-year period and thus unresponsive to changes in economic conditions. With no room for manoeuvre on the revenue side, little incentive to build reserves and governed by nominal deficit targets, spending at sub-federal levels tends to be raised during boom periods and reduced during downturns (see Brandner et al., 2009). The recently adopted Domestic Stability Pact takes into account new tax revenues of the consolidation package and the economic outlook. ${ }^{8}$ However, the current outcome of the negotiations between the federal and local governments about the distribution of consolidation burdens raises the question why only the federal level makes savings on the spending side, despite a now more favourable economic outlook. Additional tax revenues allocated to states and municipalities in case of a stronger than predicted upswing may thus be expected to be spent fully. Instead these should be used to further reduce the general government deficit - at the federal level the expenditure framework guarantees such a further consolidation. With improved budgetary rules, budgetary policy at state and municipal level could better support fiscal policy objectives at the national level.

\section{Fiscal targets need strengthening}

Existing fiscal rules such as the medium-term target of a balanced budget over the business cycle as spelled out in the Austrian Stability Programme have proven too weak. A budget rule of balance over the cycle should have produced a secularly declining debt ratio, but the debt ratio remained on average 5 percentage points above the Maastricht threshold of $60 \%$ of GDP during the decade preceding the crisis. Austrian net lending, like in many other OECD economies, has been subject to pro-cyclical movements (see Figure 6). Brandner et al. (2009) provide evidence that fiscal policy in Austria has tended to be pro-cyclical in upturns, principally because spending was not adequately kept in check. Discretionary policies tended to offset the effects of automatic stabilisers during upturns but not during downturns. Another factor has been the tendency to resort to off-budget financing which eventually showed up on government balance sheets.

Figure 6. Austrian government debt remained high

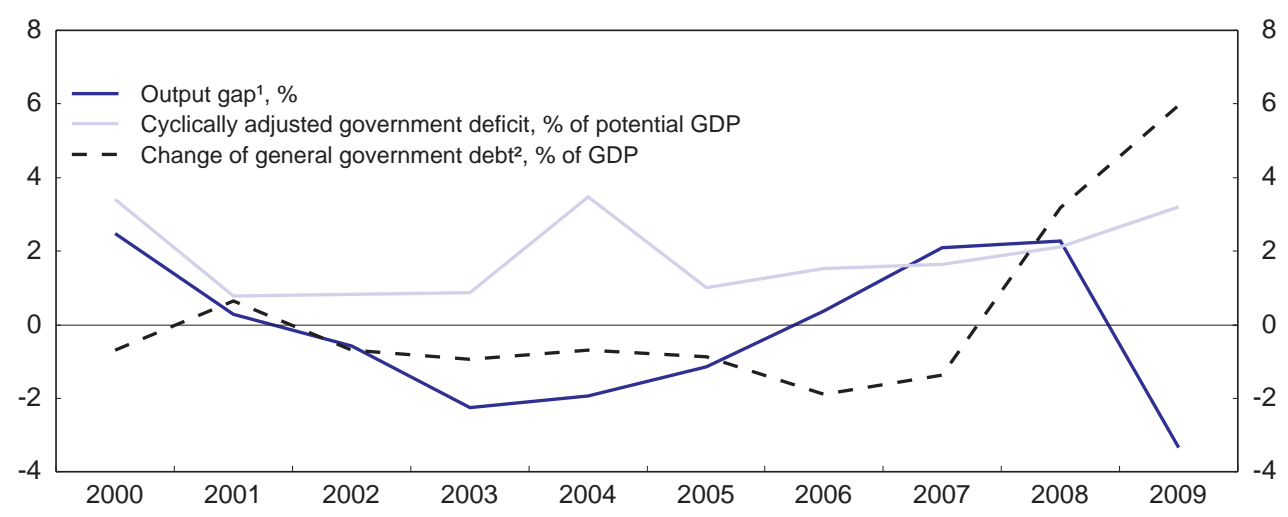

1. Output gap of the total economy.

2. General government gross financial liabilities according to Maastricht definition.

Source: OECD Economic Outlook Database.

8. In the period 2011-14, states are required to improve their budget balance by $0.25 \%$ of GDP, from $-0.75 \%$ of GDP to $-0.5 \%$ of GDP, while municipalities are required to record balanced budgets in all years. The share of additional revenues from the consolidation package allocated to sub-federal levels amounts to $0.1 \%$ of GDP in 2011 with a gradual increase to $0.2 \%$ of GDP by 2014 . 
One option to contain spending pressures in periods of revenue windfalls would be to anchor consolidation efforts in a debt rule which specifies a path to reduce the debt-to-GDP ratio. This may be supplemented by a target rate of growth of real general government spending. The advantage of such an expenditure rule as compared to a deficit rule of balance over the cycle is that it is less sensitive to cyclical conditions, which may be difficult to assess and offer room for manipulation. Under an appropriately designed rule, revenue increases in upturns will automatically be saved, which is not the case with a deficit rule (OECD, 2010d).

The challenge Austria faces is how to further involve regional governments in the consolidation efforts. A reform of inter-governmental fiscal relations will be needed to strengthen containment of expenditure dynamics and further reduce pro-cyclical tendencies. Apart from applying the medium-term expenditure framework at all levels of government, the Domestic Stability Pact should be extended towards debt and spending targets.

\section{Public spending needs to be substantially restrained}

Containing public expenditure dynamics is the first best option to durably consolidate public finances and prepare for upcoming challenges related to demographic developments, climate change adaptation or additional education needs as well as other prioritisation needs. The ultimate goal should be to provide more and better public services with less public money. Governments are not only accountable for how much they spend, but also for what they achieve with a given amount of taxpayers' money. There is thus a cost-efficiency and a quality argument. To the extent that public services can be provided with fewer resources, taxes can be lowered or spending directed to other areas in the service of growth and welfare.

Improving public sector efficiency is particularly important given the above-average ratio of expenditures to GDP (53\% of GDP in 2010, up from $49 \%$ before the crisis). Studies suggest that there is a sizeable savings potential, especially with regard to social transfers, health care, education, and business subsidies (see below), but also in public administration and public procurement. For example, strengthening public tendering processes and resorting to public-private-partnerships where they offer genuine efficiency gains can secure savings. Replacing only a fraction of retiring government employees seems to be the most effective way to reduce public wage costs. In general, the scope for raising efficiency appears to be large in areas characterised by fragmented responsibilities between different levels of government and at sub-federal levels (see OECD, 2005a; Fuentes et al., 2006).

According to WIFO (2010), the short-term savings potential in the Austrian public sector amounts to EUR 1.8 to 2.8 billion for the consolidation period 2011-13. Similar conclusions have been reached by a recent IHS study (2010), which detects an efficiency savings potential of EUR 430 to 660 million per year as a lower bound estimate. The long-run savings potential from genuine public sector reform would be significantly larger. The main reasons for inefficiencies seem to differ between the central government and the states: whereas in the former, deficiencies in strategic planning (e.g. inadequate personnel management) appear to be the most important cause for inefficiencies, at state level resistance to reform and overcapacities seem to be most relevant (ibid.).

\section{Social protection spending should be better targeted}

Large spending items naturally also contain the largest potential for efficiency gains. Compared to other OECD countries, Austria spends an above-average share of GDP on social protection, reflecting societal preferences. The upward trend in spending over the past decade will slow down somewhat with the cuts applied to family and long-term care benefits in the 2011 Budget (Schratzenstaller, 2011). 
Figure 7. Austria is among the highest spenders on social programmes
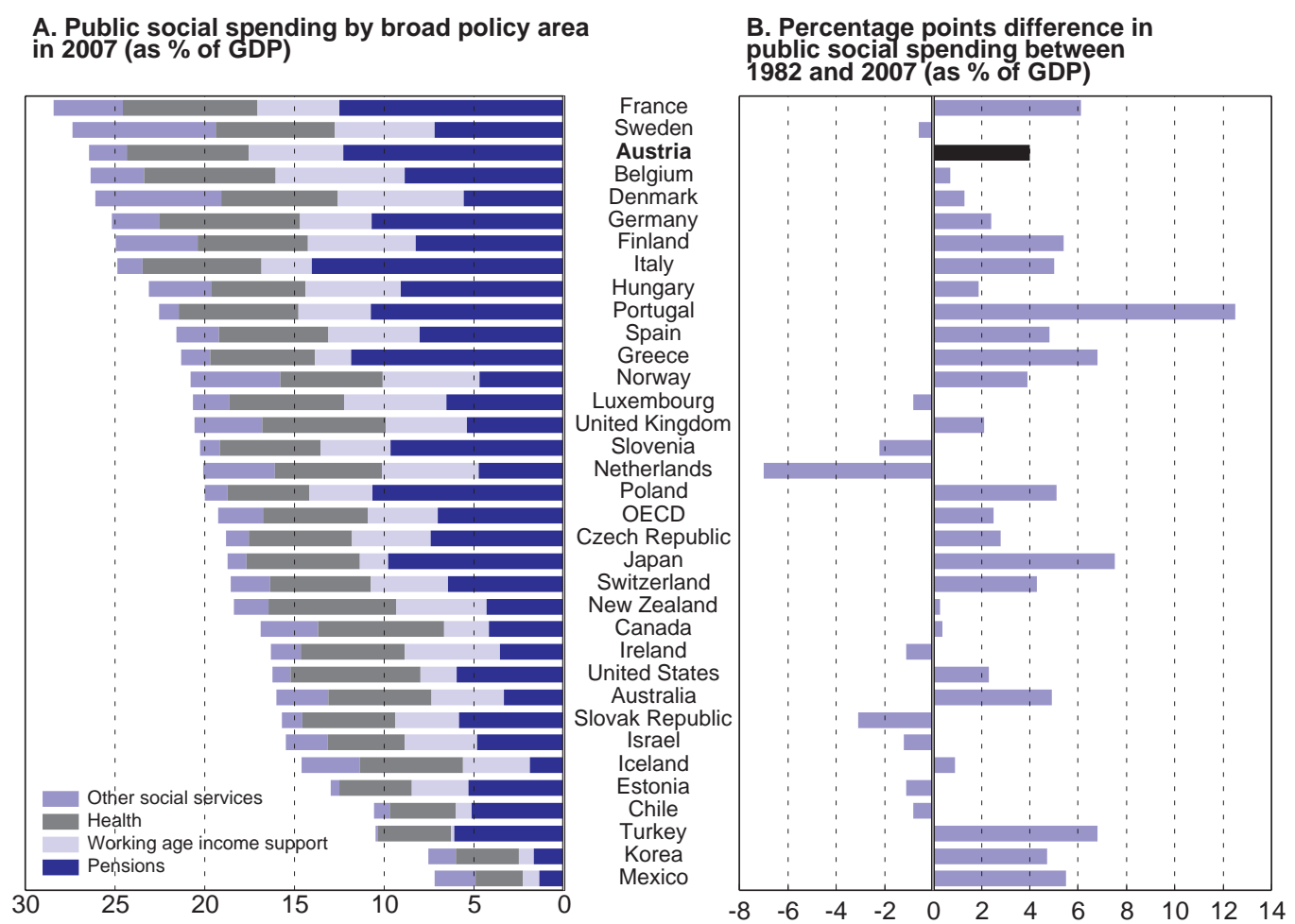

Source: OECD, Society at a Glance 2011.

Savings could be made if social transfers were better targeted. A move away from universal benefits and increased use of means-testing will be hard to avoid if the generosity of benefits is not to be severely reduced. This would be facilitated if responsibility for social spending were concentrated on one governmental level. In the area of long-term care benefits, a reform proposal to this effect has been endorsed recently, together with the updated Domestic Stability Pact. In many other areas, however, the system continues to suffer from a fragmentation of competences and a lack of coordination between the various actors, which makes means-testing difficult to apply in practice. The government has taken a first step to improve transparency by setting up a database (see Box 2). Moreover, a working group on the future of the welfare state has been established to reassess social benefits and transfers.

Housing subsidies, a sole competence of the Länder, are one example of social spending which could be better targeted. While means-tested benefits play a limited role, considerable amounts are spent on a housing promotion scheme (Wohnbauförderung), which benefits higher income earners more than lower ones, as the former are more likely to invest in home ownership than the latter (Albacete and Wagner, 2009). In addition, housing is indirectly subsidised because $i$ ) imputed income from owner occupied housing is not taxed, and ii) interest payments on housing loans are deductable from income tax up to a certain income level.

\section{Box 2. Transparency database}

Since 1 January 2011 a federal law is in force to establish a so-called transparency database, with the main aim of increasing transparency of all benefits and services provided by the public sector to natural and legal persons; to reduce the interaction costs between citizens and benefit granting authorities; and to enhance the effectiveness of public transfers. Access to the database is under the current law only granted to the recipients of benefits, however, the federal government can request aggregated and non-personal data. The database is scheduled to be operational 
by 1 January 2012 and the set-up costs are estimated to be around EUR 1.6 million with additional running costs of about EUR 2.5 million per year.

The transparency database is intended to provide a comprehensive list of all benefits including social security benefits, monetary transfers, subsidies, tax expenditures and benefits in-kind in order to enhance information availability and raise the awareness of the amount of public transfers. In the case of benefits in-kind, such as publicly subsidised access to child care facilities or the educational system, information on the average cost per beneficiary will be provided. However, under the current law, only federal benefits are covered and for the database to include benefits from states and municipalities, separate laws on the state level have to be enacted. A treaty between the federation and the states is currently negotiated with the outcome being unpredictable at the moment.

Besides informational purposes, the transparency database can be used to facilitate the interaction between natural/legal persons and benefit granting authorities. For instance, in order to apply for an additional benefit, it might be necessary to provide evidence of benefits already received. A list of these benefits can be readily obtained from the database and transferred to the authorities. This in turn enables the granting authority to easily verify the conditions for entitlements and reduces the risk of granting double-benefits.

The government can use the transparency database for controlling and evaluation purposes. Based on aggregated and non-personal data, the government obtains an overview over the instruments of state aid and their amount. In addition, analyses on the eligibility conditions for entitlements and how well they are aligned can be conducted. This may help to coordinate different benefit instruments and target them to specific groups. Access barriers for the government are high, however. Each request requires a unanimous vote of the council of ministers. Furthermore, the purpose of assessing the effectiveness of state aid might be particularly limited in the case of subsidies. Subsidies are generally granted with the aim of influencing incentives and behaviour. Thus to properly assess their effectiveness, information on outcomes would be necessary. While such an extension is currently not envisaged, the database would provide a first step by establishing the necessary infrastructure.

\section{Scope for efficiency gains needs to be identified sector-wise}

International benchmarking of public expenditure efficiency suggests that Austria is among the less efficient countries in terms of value for money from health spending (European Commission, 2008). The reasons for inefficiencies and the savings potential are discussed at length in the 2011 OECD Economic Survey of Austria. The analysis shows that the below average productivity/cost performance in the health sector may be partly related to the complexity of governance based on the fragmentation of decision making and financing between the different levels of government. A better alignment of performance, financing and spending responsibilities would thus seem to be an essential step forward in the health domain. In respect of health spending, however, the contribution of better management to budget control will be more in containing the effects of growing future demands rather than freeing up resources for alternative use or deficit reduction.

Austria is also lagging with respect to the efficiency of education spending (OECD, 2009a). One estimation (Sutherland et al., 2007) suggests that compared with international best practice, Austria could save a considerable amount of real resources and still achieve the same educational outcomes. Looking at educational outcomes as measured by student attainment at age 15 in the OECD Programme for International Student Assessment (PISA), Austria is close to international norms in terms of educational attainment but commits an above-average amount of resources. These efficiency gains in education could be achieved by reducing teacher inputs and pursuing institutional reforms. In particular, greater decision-making autonomy at the school level tends to be associated with higher levels of efficiency, while small school sizes and residence-based selection is associated with inefficiency. However, one finding from international benchmarking exercises is that teacher pay is positively related to outcomes, so here, as perhaps elsewhere in the government sector, downward relative pressure on wages could have a negative long run cost in terms of the quality of outputs.

Expenditure on higher education is a different matter. Higher-education grants comprise a relatively high proportion of public spending on education, while there is an absence of tuition fees. The absence of 
tuition fees is in contradiction to the progressivity which characterises other mainstream aspects of the Austrian fiscal system and should be reviewed. Overall, the warranted policy objective of increasing tertiary education attainment rates, together with the necessity to develop a comprehensive grant and income-contingent loan system, will put additional pressure on the share of public education spending in GDP rather than reducing it, reinforcing the need for realising efficiency reserves.

Spending on business subsidies and transfers claims twice as many resources as in other OECD countries. Again, fragmented responsibilities between different levels of government and social security bodies, a lack of co-operation between them and insufficient reporting, especially at sub-federal levels, seem to be the main reasons for inefficiencies. WIFO estimates that Austria spends 1.5 times the amount of subsidies that would be required according to structural factors (Pitlik et al., 2010). The transparency database has the potential to provide for the first time a consistent compilation of all subsidies and transfers granted by different institutions, on the basis of which a comprehensive evaluation against quantitative and qualitative performance objectives could be undertaken.

There are also efficiency reserves in the administration of the tax system and the collection of general government receivables. Several taxes, such as income taxes and social security contributions, are collected on related tax bases. If these were better integrated, synergies could be exploited and help reduce administration and compliance costs and improve efficiency of enforcement.

\section{Progress with public sector reform is sluggish}

Discussions about public sector reform have a long tradition in Austria. Successive governments have taken initiatives over the past decades aimed at increasing transparency, efficiency and service quality. The most significant reform was undertaken in the area of security policy. Between April 2003 and June 2005, Austria reformed its police force by merging several previously separated police units into one law enforcement body. The previously 45 regional police headquarters were reduced to 9, one for each Land, and about 990 administrative and low- and middle-management positions were cut and relocated to strengthen the executive branch. In addition, bureaucratic processes were harmonised, streamlined and computerised to boost efficiency. ${ }^{9}$ Another example of a successful reform is the widespread application of information technology in administrative processes - Austria is leading with e-government applications. States and municipalities have improved customer orientation by establishing one-stop-shops.

However, many key areas of the public sector have been highly resistant to reform. In February 2009 the government embarked on a new initiative and established a high-level working group on "consolidation and administrative reform", comprising the Federal Chancellor, the Minister of Finance, state governors and experts from the Court of Audit and research institutes. As of now, sub-committees have been set up to develop practical solutions on 6 out of 11 work packages and 2 sets of recommendations have been finalised and presented to the working group. The first set of recommendations of May 2009 relates to school organisation and proposes a better alignment of spending and financing responsibilities, orientation towards strategic objectives, external monitoring and school autonomy. The second set deals with the alignment of pension systems of states and public enterprises with the general pension scheme and was presented in February 2010.

In practice, progress in the working group has been slow and a lot of impetus has been lost in the preparatory committees, where diverse interests narrow down the scope of discussion and reaching consensus has proven difficult. No decision has so far been taken on issues involving a shift in power structures between the three levels of government or even between states.

9. A systematic assessment of the efficiency gains is not possible due to a lack of output measures of the old organisation. 


\section{Performance budgeting should help improve efficiency}

Increasing the use of performance information in the budget process is an important step away from the traditional input-orientation towards outcomes and results. With the adoption of the budget reform law in 2009, Austria has made a commendable first step in that direction. The traditional budget doctrine of being economical, thrifty, and useful was transformed into four principles to be applied by 2013: i) outcome orientation; ii) efficiency; iii) transparency; and iv) true and fair view (Steger, 2010). Performance budgeting is one of the main elements to be introduced in the second stage of the budget reform process scheduled for 2013. Thus the new budget framework can act as a key institutional driver to improve public sector efficiency.

The challenge is now to develop appropriate performance indicators and establish a framework for using them in the budgeting process. OECD experience suggests this is not an easy task. Despite widespread introduction of performance information in the budgeting process over the past 15 years, OECD countries continue to struggle to make appropriate use of it. A clear procedure on how to employ performance indicators in the budgeting process, the quality of information and the institutional capacity of Finance Ministry and line ministries have been found to be important success factors (Curristine et al., 2007).

In order to get the most out of the reform, performance budgeting should also be implemented at sub-federal levels of government. Fiscal relations between the federation and the states must ensure that incentives to deliver cost-efficient and effective public services exist at all administrative levels. Genuine public sector reform requires the co-operation of states and municipalities, especially because they play an important role in the provision of some of the services where the largest gaps in terms of quality and cost-efficiency have been detected.

\section{Towards a more growth-friendly tax structure}

Taxes affect employment, welfare, and economic growth through their impact on the decisions of households and firms with regard to labour supply and demand, the level and composition of investment and production, and the choice of savings channels. What matters for these decisions is not only the level of taxes but also the way in which different tax instruments are designed and combined. Empirical evidence suggests a "tax and growth ranking" with recurrent taxes on immovable property being the most growth-friendly, followed by consumption taxes and other property taxes as well as environmental taxes, personal income taxes and corporate income taxes (Johansson et al., 2008; Arnold, 2008). Recognising this, many OECD countries have undertaken structural reforms of the tax system with a view to creating work incentives, encouraging investment and entrepreneurship, and reducing tax-induced distortions (OECD, 2010a).

Austria enjoyed some success in reducing the overall tax burden from 2000 to 2007. Attempts have also been made to improve the growth-friendliness of the tax structure, reducing taxation of labour and corporate income:

- Recent reform measures reduced the labour tax burden by EUR 2.1 billion and were implemented in 2008/2009 as part of the economic stimulus package. The package included: $i$ ) an extension of the zero tax threshold and an upward shift of the top income bracket; ii) rate cuts in the second and third income brackets (from $38.3 \%$ to $36.5 \%$ and from $43.6 \%$ to $43.2 \%$ ); iii) an up to 3 percentage points reduction in unemployment insurance contributions of low-wage employees; and iv) measures to support families with children, such as an increase in the tax credit for children, the introduction of a tax allowance for children and tax deductibility of childcare costs. The earlier 2004/2005 income tax reform reduced the number of tax brackets from five to four, 
increased the standard tax credit, simplified the phasing-out rules of the standard tax credit, and introduced a child tax credit for sole earners and lone parents.

- An Act to promote small- and medium-sized enterprises came into effect in 2007, introducing a tax allowance for reinvested profits in certain assets. The 2009 tax reform expanded the tax allowance to all firms under income tax law and softened the reinvestment criteria, while eliminating the preferential taxation of non-distributed profits and stock options.

Despite these recent improvements, there remains significant scope to further increase the growth-friendliness of the tax structure. Figure 8 shows the composition of tax revenues by major tax category. Compared to the OECD average, direct taxes on income and social security contributions are relatively important, while the proportion of taxes on property and consumption is lower. Over time, the share of growth-friendly taxes was reduced at the expense of more distortive ones. Austria now funds one of the largest public sectors in the OECD, while at the same time largely foregoing opportunities to raise revenue in a non-distortive way.

Figure 8. The tax structure is biased towards distortive taxes on labour

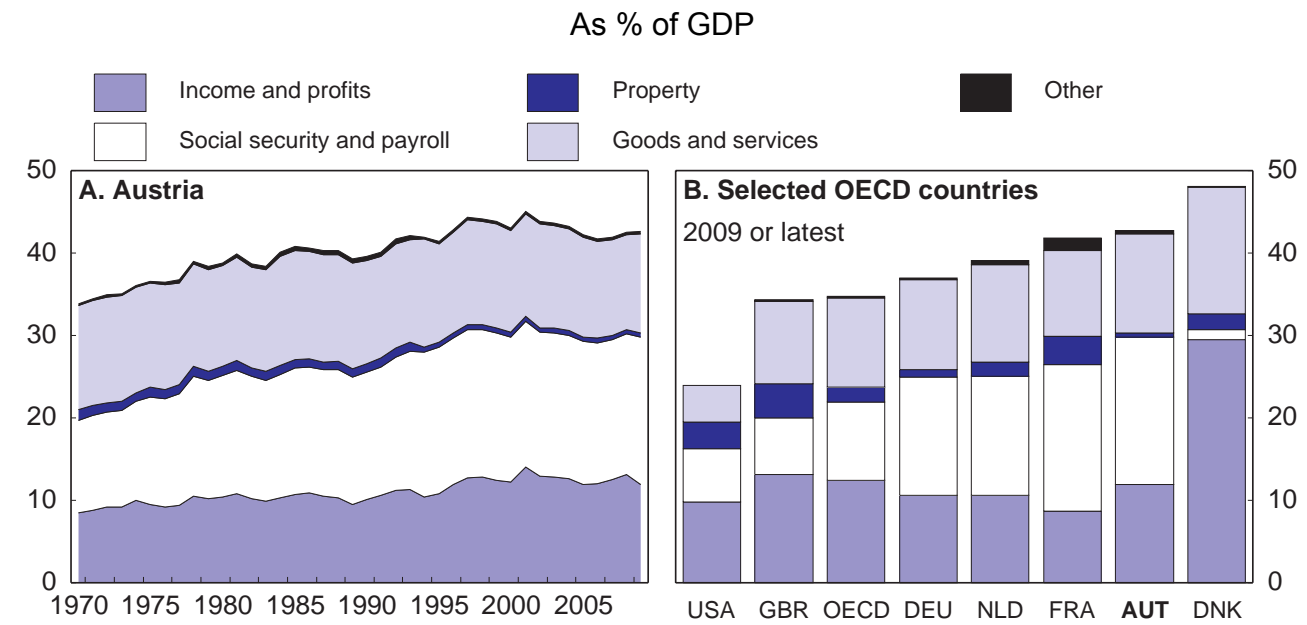

Source: OECD, Revenue Statistics Database. 
Figure 9. Labour tax wedges are among the highest in the OECD

$\%$ of labour costs, 2009

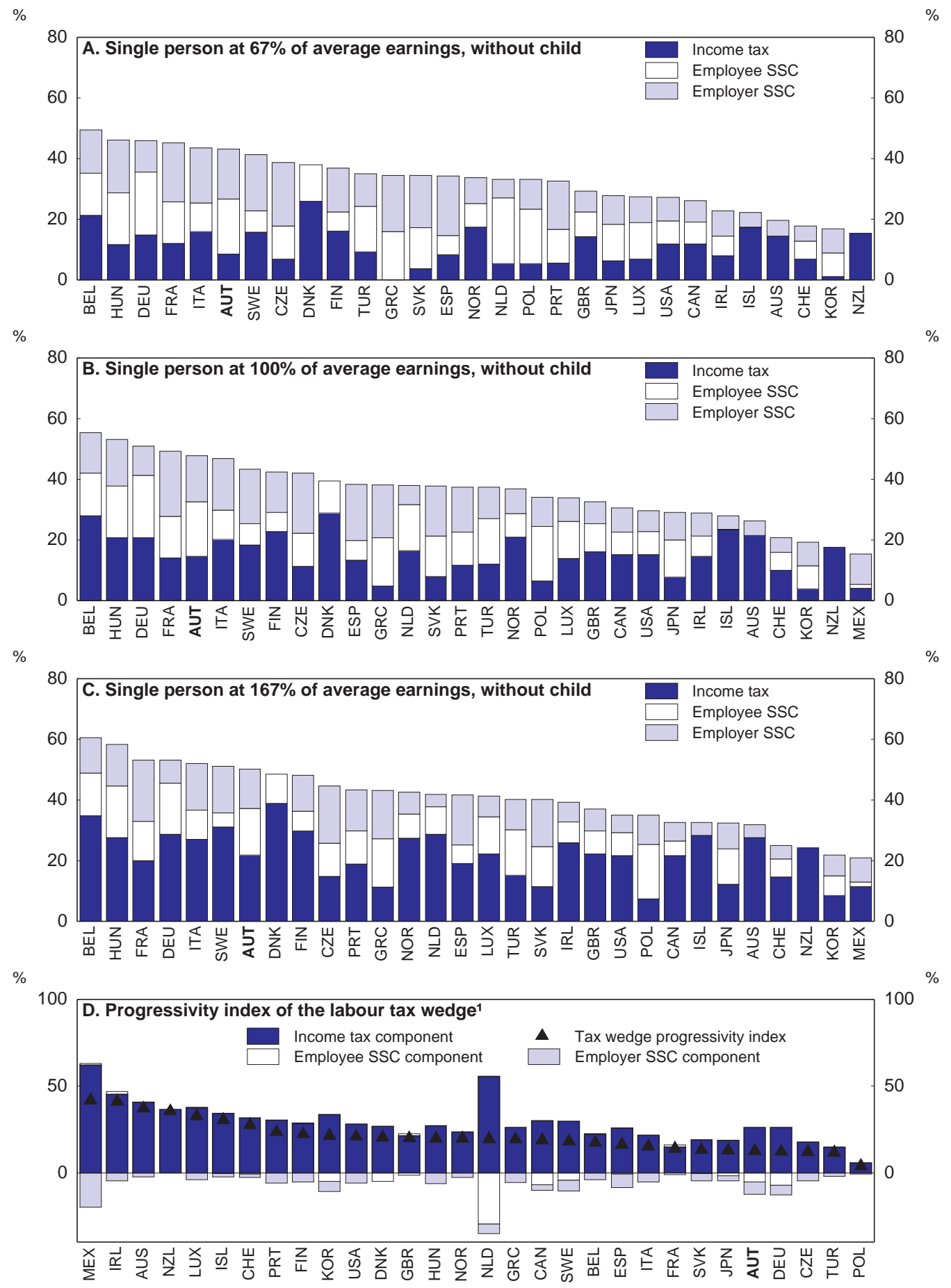

1. The progressivity index of the tax wedge is calculated as (TW167 - TW67)/TW167, where TW167 and TW67 is the tax wedge for workers at $167 \%$ and $67 \%$ of average wage, respectively. The index here is calculated for a single person with no children.

Source: OECD, Taxing Wages Database. 
Austria is among the countries in the OECD with the highest tax wedge on labour income, at $48 \%$ for the average earner. ${ }^{10}$ Empirical evidence suggests a high tax wedge between gross wages paid by employers and workers' take home pay reduces employment (OECD, 2007b). Other things being equal, a higher tax wedge reduces the net financial gain from work and thus tends to depress labour supply. Opportunities for undeclared work reinforce this effect.

The Austrian labour market performs well with low unemployment and an above-average employment rate, but a considerable performance gap exists between the core of the labour force (men and women between 25 and 54 years with at least upper secondary education) and some vulnerable groups (see OECD, 2009a), who could be helped by reducing the fiscal burden on them:

- Older workers: The employment rate of workers aged 55 to 64 remains among the lowest in the OECD, despite some progress in recent years. In 2009 , it stood at $42 \%(52 \%$ for men and $32 \%$ for women), up from $33 \%$ in 2005 (43\% for men and $24 \%$ for women), but still far below the OECD average of $57 \%$.

- Female workers: The labour market potential of women is not fully exploited, even though progress has been made in increasing the employment rate to $66 \%$ in 2009 , up from $62 \%$ in 2005 . The increase was however driven by a rise in part-time work, which approached levels far above the OECD average. In $200944 \%$ of employed women worked part-time, as compared to $39 \%$ in 2005 (Statistics Austria). This contrasts with just 9\% of male part-time employment and 26\% of female part-time employment in the OECD.

- $\quad$ Low-skilled and migrant workers: The gap between employment rates of low-skilled workers as compared to workers with intermediate or higher education is higher than in other OECD countries, suggesting that there is room for improvement. Migrant workers are unemployed twice as often as native-born workers.

\section{Reforms should target low-income groups}

Periodic efforts to reduce the tax burden on labour income have focused on the income tax, which is the relatively less important part of the total labour tax wedge (see Figure 10 and Box 3). The reductions were not sustained, because "fiscal drag" effects quickly neutralised the effects of reform. Tax brackets are not indexed to inflation so that over time nominal income growth pushes more and more taxpayers into higher tax brackets even tough real earnings may not have increased. The 2009 income tax reform, for example, reduced the tax rate of an average earner by 1.3 percentage points, but the tax rate was still 1.8 percentage points above the level in 2000 (OECD, 2010b). The reforms have also failed to address workers at the lower end of the earnings distribution, whose taxable income does not normally exceed the tax free threshold, while however, being fully subject to social security taxation.

While average tax rates are high for almost all workers, marginal tax rates are particularly high at low income levels, due to the interaction of social security contributions, personal income tax and the benefit system (see Boxes 3 and 4). This reduces incentives for transition from inactivity to employment and from part to full-time employment. High marginal tax rates also negatively affect incentives to invest in skill-upgrading, reducing the amount of training and education among the group of workers that would be most in need of it. There is thus a risk of locking the low-skilled into "low-wage traps", when the financial

10. The tax wedge combines the effect of in-work taxes and out-of-work benefits, i.e. personal income taxes and social security contributions on the one hand, and social benefits and entitlements on the other hand. It is defined as average income taxes plus employee and employer social security contributions minus cash transfers as a percentage of total labour costs. 
returns of higher work effort are too low to be considered a sufficient return relative to remaining on a benefit programme.

Figure 10. Average and marginal tax wedges decomposition

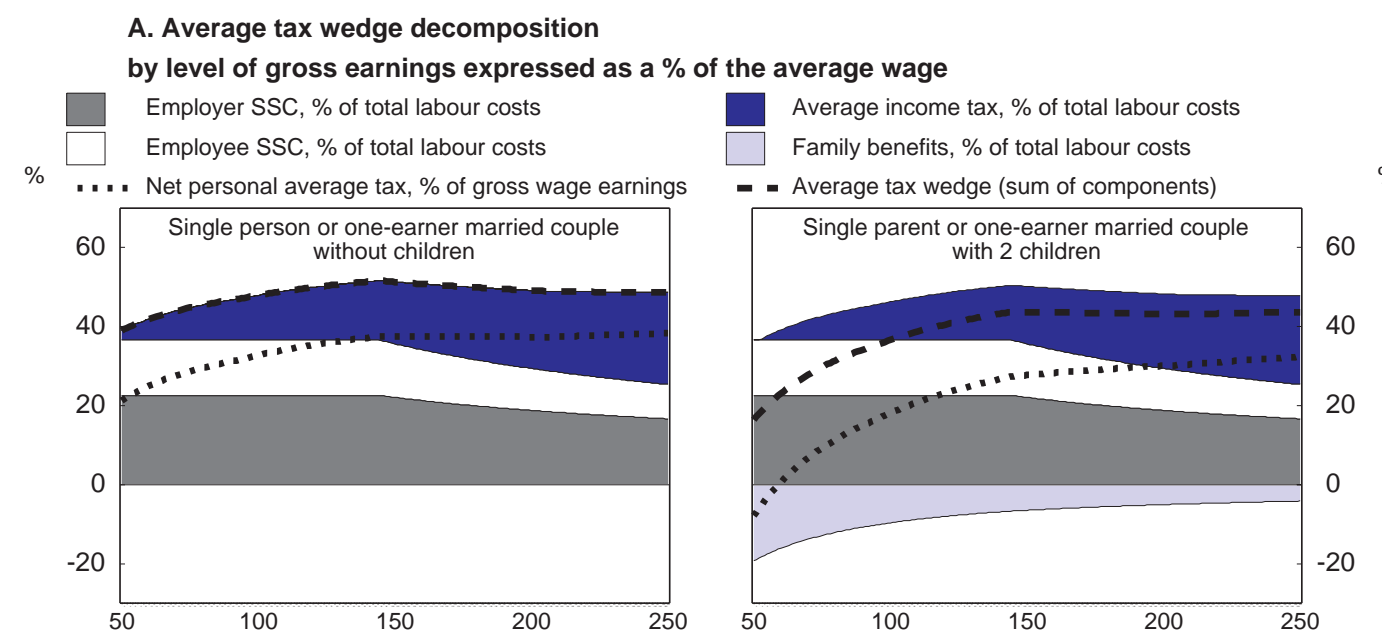

B. Marginal tax wedge decomposition

by level of gross earnings expressed as a \% of the average wage

\begin{tabular}{l}
$\square$ Employer SSC, \% of total labour costs \\
$\square \quad$ Employee SSC, \% of total labour costs \\
\hline 70 . . Net personal average tax, \% of gross wage earnings
\end{tabular}

Average income tax, $\%$ of total labour costs

Family benefits, \% of total labour costs

- Average tax wedge (sum of components)
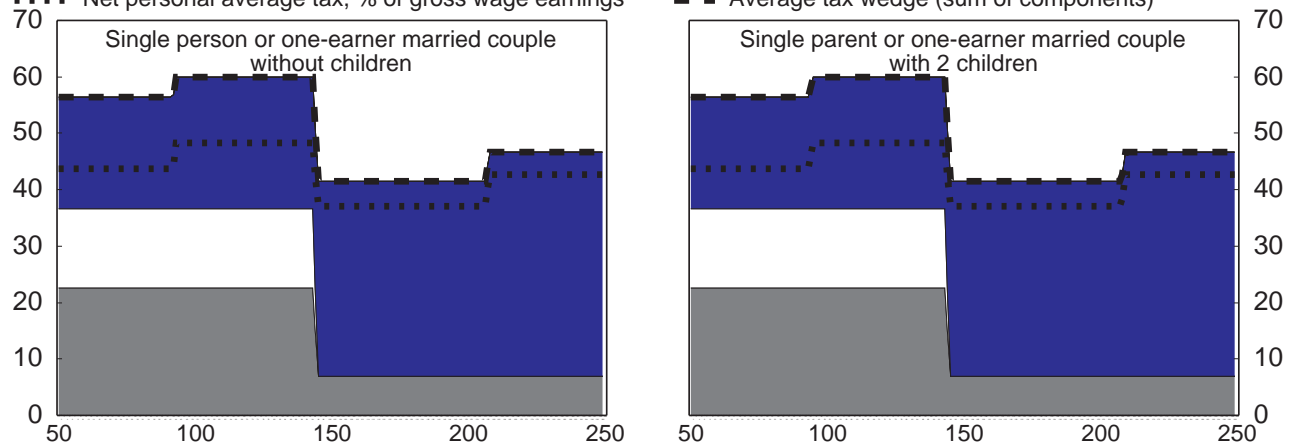

Source: OECD Taxing Wages 2010.

\section{Box 3. Main taxes on labour income}

Social security contributions are levied at a rate of about $40 \%$ on all earnings exceeding EUR 374 per month and up to a cap of EUR 4200 (about 140\% of the average wage; data for 2011). They are shared between employers $(22 \%)$ and employees $(18 \%)$ and both the lower and upper thresholds are adjusted annually. Since 2008 up to 3 percentage points lower rates have been applied to low incomes. Social security contributions are the largest tax by volume, yielding $35 \%$ of total tax revenues in 2009 . Their effect is regressive and hurts low and average incomes disproportionately.

Income taxation is progressive with four tax brackets and a tax-free threshold of EUR 11000 on gross wages less social security contribution. Most of the progression is taking place at relatively low income levels, with the marginal tax rate increasing from zero to $36.5 \%$ at around $50 \%$ of the average wage. A special tax rate of $6 \%$ is applied to the so-called Christmas and leave bonuses of dependent wage income recipients to the extent that their sum does not exceed $1 / 6$ of annual income. The latter benefits higher income earners, who also gain 
disproportionately from tax allowances for children, childcare costs, and work related expenses, thus decreasing the maximum effective marginal income tax rate to $44 \%$ (from the statutory rate of $50 \%$ ) and reducing the progressive element in the system. Income tax on wages yielded 18\% of total revenues in 2009.

Payroll taxes other than social security contributions are levied on all private sector wage incomes exceeding EUR 1460 per month. They include the contribution to the Family Burden Equalisation Fund (4.5\%), the Community Tax $(3 \%)$, and the contribution for the promotion of residential building $(0.5 \%)$. In addition, all private sector workers contribute to the Labour Chamber (about 0.5\%). Payroll taxes accounted for $7 \%$ of tax revenues in 2009 and add another proportionate element to the labour tax burden.

Labour income taxation (wage tax, social security contributions and payroll taxes) is characterised by high total marginal and effective taxation at below average income levels, whereas progression flattens out at higher earnings. For low and average earners $(67 \%$ and $100 \%$ of the average wage respectively), the total marginal tax rate is among the highest in the OECD ( $44 \%$ and $48 \%$ respectively), while for high income earners ( $167 \%$ of the average wage) it is significantly below the OECD average (37\%). High incomes experienced a decrease in the marginal tax rate over the past decade, whereas low and average incomes faced a 3 to 7 percentage points increase. Total average tax rates are $27 \%, 33 \%$ and $37 \%$ for low, average and high income earners respectively and have increased over the past decade by 1 percentage point at the lower and upper ends and by 2 percentage points at the average income level (OECD, $2010 \mathrm{~b})$. Over time, the labour tax system has become less progressive and today's structure resembles in many aspects a flat tax system with a relatively large basic tax allowance, also due to numerous tax deduction possibilities of a multitude of saving vehicles.

The fiscal burden tends to be stronger for women for two main reasons. First, for married couples with children there is a "joint element" in the tax system in the form of the sole earner's tax credit (EUR 494 per year plus EUR 175 for the second and EUR 220 for the third and every additional child), granted as long as the spouse's income does not exceed EUR 6000 per year. Thus there is a jump in the tax rate as the second earners' employment goes beyond a marginal job. And second, working hours of second earners have been found to be more responsive to taxation than that of principal earners, thus the economic distortion of high marginal taxation tends to be stronger for women (Causa, 2009).

Several OECD countries with high labour income taxation have responded to the challenge of increasing employment rates of low-skilled workers by granting rate reductions or exemptions. Austria has made a first step into that direction by reducing unemployment insurance contribution rates for low-wage workers. Measures have also been taken to increase incentives for employers to hire low-skilled workers, including an in-work benefit scheme for specific age cohorts in low-wage jobs (Kombilohn) and subsidies for recruiting long-term unemployed (Eingliederungsbeihilfe) (see OECD, 2009a).

Childcare costs and the availability of childcare institutions also play a role in parents' work decisions. For parents with limited earnings potential, the costs of childcare might reduce the financial reward of full-time employment and therefore make reconciling work and family obligations expensive. Austria has recently introduced half-day free of charge childcare for 5-year olds, and some Länder have gone beyond that by offering free half- or full-day care also for younger children. It remains to be seen whether these measures are sufficient to facilitate full-time labour force participation of low-skilled women. The tax allowance for childcare costs introduced in 2009 fails to appropriately address this group of workers, as their taxable income may not exceed the zero tax zone. Low enrolment rates of children below age three in formal childcare (less than 20\%) also suggest that there is an undersupply of good-quality childcare facilities for the very young. More often than in other high-income OECD countries, labour market availability of women is held back because of care responsibilities (Budimir et al., 2010). Investment in high-quality childcare institutions is therefore crucial to increase full-time labour force participation of women. This could be financed partly by better targeting monetary spending for families. 


\section{A cut in the labour tax wedge could lead to sizeable employment gains}

Estimates by the OECD suggest that a cut in the average labour tax wedge could lead to sizeable employment gains. According to Bouis and Duval (2011), the employment rate in Austria could be raised by $2.4 \%$ within 10 years following a reduction of the average labour tax wedge to the level observed in the six OECD countries with the highest employment rate. Shifting progressivity in the labour tax system upwards would help alleviate adverse employment incentives at low income levels. This would also be consistent with equity goals, given that the wage differential has increased over the past decade, with losses up to the third quintile of the earnings distribution and gains for the fifth quintile (Guger and Knittler, 2008). Cuts in the tax burden for low-income workers have also been recommended by the OECD as a way to boost consumption, as this group is more likely to spend rather than save additional net earnings (OECD, 2009b).

Wage flexibility at the lower end of the earnings scale has been considered one of the strengths of the Austrian economy. However, high marginal effective taxation of transition to employment risks locking people into "unemployment traps" or "inactivity traps", if the net income gain is too low to "make work pay" (OECD, 2007a). Reducing social assistance benefits might not be a politically viable option to encourage work, because it conflicts with poverty and income distribution goals. Measures should therefore be taken to reduce the effective tax burden at low earnings levels or introduce in-work benefits that top up wages. The government should also consider providing more in-kind benefits in the form of childcare facilities for children below age three to allow for more continuous female work careers and facilitate a decrease in the gender wage gap in the medium- to long-term. Better targeting of social transfers to needy parents would limit the strain on government budgets while addressing barriers to work for those who are most likely to respond to stronger work incentives. The quality of enforcement of work availability rules continues to be important to keep beneficiaries in the labour market.

\section{Box 4. Social benefits and effective taxation of labour income}

Withdrawal of unemployment or social assistance benefits can significantly reduce the financial incentives for taking on a job or transiting from part-time to full-time employment. For someone considering a move into employment, the relevant question is how much this adds to available income. An analysis of employment incentives would thus be incomplete without giving due consideration to the availability of out-of-work social assistance.

Policy makers try to accomplish three main goals when designing benefit systems: support the living standard of low-income families; encourage work; and keep the costs for taxpayers low (OECD, 2007a). Austria fares well as regards the first goal, with poverty rates below the OECD average. There remains however room for improvement as regards work incentives. A high level of social protection is not necessarily in conflict with high labour market participation and employment, as the Scandinavian model of high taxes, high social protection and high total hours worked shows (see Causa, 2009). Rather it is the pattern of government spending and revenues, together with the enforcement of work availability rules, which matters. Negative employment effects are stronger in the case of lump-sum transfers but can be largely avoided if the size of the transfer depends on the amount of labour supplied. A low tax and contribution burden or in-work benefits that top up earnings might be best suited to improve work incentives while at the same time avoiding poverty traps.

Unemployment insurance benefits are paid out for up to one year and to a maximum of $55 \%$ of previous net earnings, subject to work availability. There is a supplement for people with low net earnings, but replacement rates generally do not exceed $60 \%$ in the case of no dependents and $80 \%$ with dependents. After exhaustion of unemployment insurance benefits, needs-based unemployment assistance (Notstandshilfe) to the amount of $92 \%$ of the previous unemployment insurance benefit (95\% for low-income groups) is available. Benefit recipients can earn up to EUR 374 per month (Geringfügigkeitsgrenze) with the benefits remaining unaffected. In the case of unemployment assistance, there is a limit to what spouses can earn before benefits are withdrawn. A new needs-based basic income scheme (Mindestsicherung) was introduced as of September 2010, replacing the former social assistance, which differed between states as regards eligibility conditions and payment rates. Support is provided to households with earnings below the social assistance threshold of currently EUR 744 for sole persons and EUR 1116 for couples. There are top-ups for children which vary between states but are at least EUR 134 per child. 
Given that wages of low-skilled workers in a number of occupations such as commerce, tourism, or the publishing industry are not much above EUR 1000 per month (35\% of the 2009 average wage), yielding net earnings of around EUR 850, there often appears to be little financial gain from employment. Such low earnings also do not benefit from tax credits or tax allowances, though negative tax is possible upon application. Single persons without dependents are paid out up to EUR 240 per year in the following year, and for sole earners/sole parents with children, the amount increases by the respective tax credit (EUR 494 per year plus EUR 175 for the second and EUR 220 for the third and every additional child). However, for a sole earner with two children taking up work at a wage level of EUR 1000 per month hardly pays. The annual net income from employment would be around EUR 12700 , whereas income from social assistance would amount to EUR 12150.

\section{Fiscal disincentives are depressing employment at older ages}

The employment rate of older Austrians is among the lowest in the OECD. More than two thirds of workers withdraw from the labour market before reaching the statutory retirement age $(65 / 60$ for men/women, with women's retirement age increasing to that of men between 2024 and 2033) and many even before reaching the early retirement age (62/57 for men/women, with a gradual increase to 65 for men and 60 for women until 2017). On average, male Austrians retire at age 59 and females at 57 . Only $28 \%$ of new pensioners ${ }^{11}$ in 2010 took the regular route to old-age pension, whereas $31 \%$ were granted disability pension and $41 \%$ benefitted from other early retirement schemes [ $67 \%$ of which from the special early retirement scheme for long-term contributors (Hacklerregelung)] (Federal Ministry of Labour, Social Affairs and Consumer Protection). Excess inactivity of older workers poses a heavy toll on the economy and the sustainability of the social system. An extension of work careers would not only curb age-related spending, but also raise economic growth and generate higher tax revenues.

A key summary indicator of retirement incentives is the implicit tax on continued work, which represents the balance between economic costs (in terms of foregone benefits and contributions paid) and benefits and captures the effects of eligibility ages and the benefit level. Austria is among the countries in the OECD where such implicit taxes on continued work are highest, reaching almost $60 \%$ of average earnings. Adverse work incentives for persons aged 55 to 64 have been reduced over the past decade, but strong disincentives to continue work at older ages remain. Estimates suggest that the gains from reforming retirement schemes in terms of an increase in the employment rate would be particularly high (Bouis and Duval, 2011).

Figure 11. Average implicit tax on continued work at older ages

2009, percentage of average worker earnings

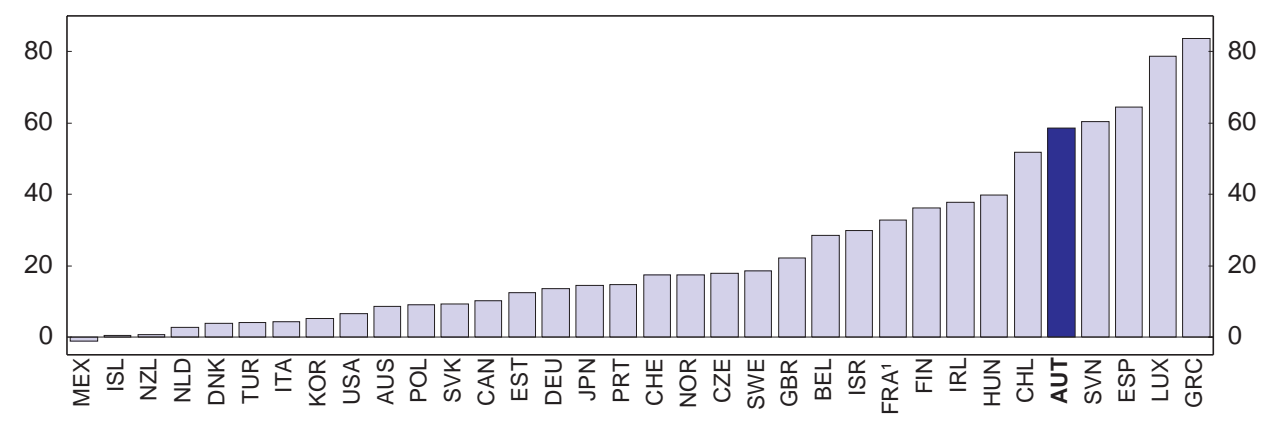

Note: Implicit tax on continued work in early retirement, average for 55 and 60 -year-old workers.

1. For France, year 2010.

Source: OECD calculations based on Duval (2003),"The Retirement Effects of Old-Age Pension and Early Retirement Schemes in OECD Countries", OECD Economics Department Working Papers, No. 370.

11. Excluding survivor pensioners. 
Pension benefits are more generous than in most other OECD countries. The net replacement rate (individual net pension entitlement divided by net pre-retirement earnings) in Austria varies between 78\% (blue collar workers) and $85 \%$ (white collar workers) depending on the duration and steepness of the income career (Federal Ministry of Labour, Social Affairs and Consumer Protection) - significantly above the OECD average of $70 \%$. Penalties for early retirement are limited and so are benefits from continued work. Pensions are adjusted by $4.2 \%$ for each year the pension is claimed early or late, but deductions and increments are capped (deductions at 15\% and increments at around 12\%) and exemptions exist for some early retirement schemes, with no discount whatsoever in the case of the "Hacklerregelung" (see below) and a reduced discount for "corridor pensions". Other countries such as US, Canada, the Czech Republic, Japan and Spain impose a much higher early retirement penalty of $6 \%$ per year or more. The adjustment that would be needed for actuarial neutrality, i.e. neither subsidisation nor penalisation of retirement at different ages, has been calculated at around $7.5 \%$ by the OECD and at about $6 \%$ by Austrian experts (OECD, 2005b; Federal Ministry of Labour, Social Affairs and Consumer Protection, on the basis of Brunner and Hoffmann, 2010).

The statutory retirement age is in line with OECD practice but undermined by the availability of generous early retirement and disability schemes:

- A special early retirement scheme ("Hacklerregelung") is in place for persons with a long contribution history, granting entitlement to undiscounted pension benefits from $60 / 55$ years for men/women subject to $45 / 40$ contribution years (40/40 contribution years in the public sector). The scheme has become the most common way into early retirement and is particularly popular among public sector employees. A law was passed in 2010 which will tighten access to the scheme from 2014 onwards and is expected to halve the inflow.

- The pension system allows for the retroactive purchase of up to 9 contribution years for secondary and tertiary education after age 15 . Making use of the provision has become three times more expensive for prospective pensioners as of 2011 and it is planned to be phased out in 2014. Up to then, however, it remains an attractive option and comes at a high cost for the social system. The provision is inherently regressive because it benefits better educated workers with more school and university years.

- Eligibility criteria for invalidity pensions continue to be generous in international comparison. Given that the health status of the Austrian population is above average in the OECD, the high rate of incapacity among the working age population does not appear to be justified. Contrary to OECD practice, disability is assessed against one's own occupation (Berufsschutz), implying that some workers can claim disability benefits even though they might be able to work in other occupations. Invalidity pensions may therefore constitute an alternative pathway into early retirement. As of January 2011, eligibility to disability pension has been tightened, with rehabilitation now being mandatory before a pension can be claimed. The government has also implemented a programme for early identification and prevention of work-related health problems based on best practice examples in Finland and the Netherlands, which aims to increase the average effective retirement age by 1 year within 5 years.

It is often argued that encouraging people to work longer will deprive younger workers of jobs. A recent OECD report (2011) however demonstrates that the idea that policy can re-shuffle jobs between workers of different ages is not true. Employability problems of older workers should be addressed via better education, life-long learning and retraining opportunities. OECD comparison shows that Austria has room for improvement in this area. The age gap in training is particularly large; older Austrians are less likely to take part in training compared to their younger colleagues than in most other OECD countries (ibid.). 


\section{Income from capital is taxed unevenly}

A notable feature of personal income taxation has been the non-taxation of capital gains, except for speculative gains. The treatment of capital gains differs widely among OECD economies, with varying impact. On the one hand, omitting to tax capital gains means that a feature of the Austrian tax system has been that it has not led to artificial revenue buoyancy during times of asset booms: the fact that OECD country deficits have been affected by fluctuations in asset prices, via the sensitivity of asset-related taxes to such movements, distorts underlying budget trends in some countries. There are thus advantages in terms of yield stability and predictability. National autonomy over capital tax rates may be diminished where capital is internationally mobile - a factor which prevents corporation tax from being a revenue-raising base - but in the case of capital gains tax the usual effect of taxing capital gains at a lower rate than ordinary income is that there is a conduit for tax avoidance. No evidence exists on this for Austria, but in Norway, for example, there is.

From 2012 onwards realised capital gains will be taxed evenly at a rate of $25 \%$. This new capital gains tax applies to profits from the sale of shares, bonds, funds and derivatives. 
Table 6. Tax treatment of capital gains and interest deductibility for individuals

2010, Resident taxpayer

\begin{tabular}{|c|c|c|c|c|c|}
\hline & \multicolumn{2}{|c|}{ Residential property } & \multirow[b]{2}{*}{ Shares } & \multirow{2}{*}{$\begin{array}{l}\text { Rate and } \\
\text { regime }\end{array}$} & \multirow{2}{*}{$\begin{array}{l}\text { Mortgage } \\
\text { interest } \\
\text { deductibility }\end{array}$} \\
\hline & $\begin{array}{l}\text { Principal } \\
\text { residence }\end{array}$ & Other & & & \\
\hline Austria & $\begin{array}{l}\text { Not } \\
\text { included in } \\
\text { taxable } \\
\text { income, } \\
\text { except } \\
\text { speculative } \\
\text { gains } \\
=\text { disposal } \\
\text { within } \\
2 \text { years for } \\
\text { immovable } \\
\text { property }\end{array}$ & $\begin{array}{l}\text { Not included in } \\
\text { taxable income, } \\
\text { except speculative } \\
\text { gains = disposal } \\
\text { within } 10 \text { years for } \\
\text { immovable property }\end{array}$ & $\begin{array}{l}\text { Not taxable until } 2011 \text { ex. } \\
\text { speculative gains, since } \\
2011 \text { subject to a } 25 \% \\
\text { withholding tax }\end{array}$ & $\begin{array}{l}\text { Normal } \\
\text { income tax } \\
\text { rate on } \\
\text { speculative } \\
\text { gains on } \\
\text { immovable } \\
\text { property; } \\
25 \% \\
\text { withholding } \\
\text { tax on } \\
\text { shares }\end{array}$ & $\begin{array}{l}\text { Deductable } \\
\text { up to a } \\
\text { certain } \\
\text { income } \\
\text { level; } \\
\text { subsidised } \\
\text { savings } \\
\text { plans and } \\
\text { generous } \\
\text { housing } \\
\text { subsidies }\end{array}$ \\
\hline Belgium & \multicolumn{2}{|c|}{$\begin{array}{l}\text { Not taxable except on sale of } \\
\text { undeveloped immovable property } \\
\text { within } 8 \text { years and developed } \\
\text { immovable property within } 5 \text { years }\end{array}$} & $\begin{array}{l}\text { Not taxable except } \\
\text { speculative transactions }\end{array}$ & $\begin{array}{l}\text { Normally } \\
\text { zero; } 33 \% \\
\text { on } \\
\text { speculative } \\
\text { transactions; } \\
16.5 \% \text { on } \\
\text { short-term } \\
\text { immovable } \\
\text { property } \\
\text { gains }\end{array}$ & $\begin{array}{l}\text { Deductible } \\
\text { up to } \\
€ 2770 \text { for } \\
\text { first } \\
\text { ten years } \\
\text { and } \\
€ 2080 \\
\text { thereafter }\end{array}$ \\
\hline Denmark & Exempt & $\begin{array}{l}\text { Taxable as capital } \\
\text { income }\end{array}$ & $\begin{array}{l}\text { Taxed as income from } \\
\text { shares }\end{array}$ & $\begin{array}{l}28 / 43 / 45 \% \\
\text { above } \\
\text { ceiling }\end{array}$ & $\begin{array}{l}\text { Deductible } \\
\text { from capital } \\
\text { income }\end{array}$ \\
\hline Germany & \multicolumn{3}{|c|}{$\begin{array}{l}\text { Not taxable until } 2010 \text {, ex. speculative gains: } 1 \text { year for shares and } \\
10 \text { years for immovable property }\end{array}$} & $\begin{array}{l}\text { Normally } \\
\text { zero; } \\
\text { speculative } \\
\text { gains taxed } \\
\text { at income } \\
\text { tax rates }\end{array}$ & $\begin{array}{l}\text { Not } \\
\text { deductible }\end{array}$ \\
\hline Netherlands & \multicolumn{3}{|l|}{ Not taxable } & Zero & \multirow{2}{*}{$\begin{array}{l}\text { All interest } \\
\text { payments } \\
\text { deductible } \\
\text { for } \\
30 \text { years } \\
\text { Deductible } \\
\text { from capital } \\
\text { income }\end{array}$} \\
\hline Sweden & $\begin{array}{l}\text { Tax } \\
\text { deferrable if } \\
\text { new } \\
\text { permanent } \\
\text { residence } \\
\text { purchased }\end{array}$ & 22/30ths taxable & $\begin{array}{l}\text { Included in income from } \\
\text { capital }\end{array}$ & $\begin{array}{l}\text { Flat rate tax } \\
\text { on capital } \\
\text { income: } \\
30 \%\end{array}$ & \\
\hline Switzerland & \multicolumn{2}{|c|}{$\begin{array}{l}\text { Subject to a real estate gains tax } \\
\text { declining with period of ownership }\end{array}$} & $\begin{array}{l}\text { Exempt except for } \\
\text { professional share dealing }\end{array}$ & $\begin{array}{l}\text { Cantons set } \\
\text { their own tax } \\
\text { rates }\end{array}$ & $\begin{array}{l}\text { Deductible } \\
\text { with limits }\end{array}$ \\
\hline
\end{tabular}

\section{The property tax base is eroding}

A further aspect of the uneven taxation of capital, which is potentially of even greater significance, relates to real estate. The share of property taxes is very low by international standards (Figure 12), mainly because the assessed values of land and buildings (Einheitswert) have hardly been adjusted over the past 
decades. The last assessment (Hauptfeststellung) was carried out in 1972, and updates since then have raised valuations by only $35 \%$ as compared to an increase consumer prices by about $250 \%$ (Böheim et al., 2010). In 2009 , the government generated only $0.6 \%$ of GDP or $1.3 \%$ of total revenues from property taxes, as compared to OECD averages of $1.8 \%$ and $5.4 \%$ respectively.

Raising the share of property taxes in GDP to the OECD average would yield extra revenues of EUR 3 billion per year. This would be a relatively efficient way of reducing the burden on more growth-hampering revenues. Such taxes have an advantage over income taxes because they are less distorting and levied on a relatively immobile tax base. ${ }^{12}$ Moreover, where they are low or absent, investment incentives may be biased towards property investment, to a degree which may be amplified or offset by not taxing capital gains or allowing tax relief against mortgage interest. No national house price index exists in Austria to be able to assess the effects. Nevertheless, it is recommended that revenues from real estate taxes be increased, which would require upgrading outdated valuations of real estate and land.

Figure 12. Taxes on property are very low in international comparison

$2008^{1}, \%$ of total fiscal revenues

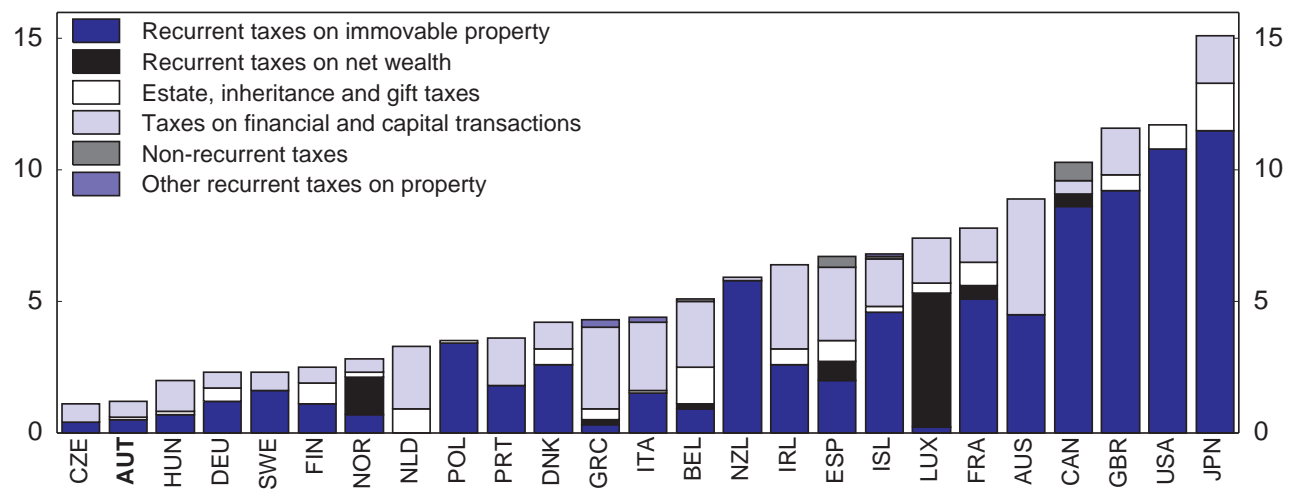

1. 2007 for Australia, Greece, the Netherlands and Poland.

Source: OECD calculations based on OECD Revenue Statistics 2010.

Other taxes on property include inheritance and gift taxes, which are also negligible in Austria, while other high-income OECD countries raise up to $0.5 \%$ of GDP from this source. In fact, the Austrian reform process has pushed towards the relaxation of capital taxes: the inheritance and gift taxes were allowed to expire in 2008 after the assessment of the tax base was ruled unconstitutional by the Constitutional Court. International practice differs greatly, but the reinstatement of these taxes should be considered, within the wider context of a review of capital taxation in general.

12. Recurrent taxes on residential property may have a long-term impact on a country's or region's attractiveness as a location for residential investment. 
Table 7. Inheritance, estate and gifts taxes

\begin{tabular}{lcc|c}
\hline & $\begin{array}{c}\text { Estatel } \\
\text { Inheritance }\end{array}$ & Gift & $\begin{array}{c}\text { Weight in total } \\
\text { RS4300 } \\
\text { tax revenues } \\
\%^{1}\end{array}$ \\
\hline Austria & Tax imposed (Y) or not (N) & 0.0 \\
Belgium & \multicolumn{2}{c}{$\mathrm{N}$ (from Aug 08) } & 0.9 \\
Denmark & $\mathrm{Y}$ & $\mathrm{N}$ after 2 yrs & 0.5 \\
Germany & $\mathrm{Y}$ & $\mathrm{Y}$ & 0.4 \\
Netherlands & $\mathrm{Y}$ & $\mathrm{Y}$ & 0.7 \\
Sweden & $\mathrm{Y}$ & $\mathrm{Y}$ & 0.0 \\
Switzerland & $\mathrm{N}$ & $\mathrm{N}$ & 0.9 \\
\hline
\end{tabular}

1. Period average.

2. In the case of non-registered accounts, capital gains are recognised and become taxable on the final return of the deceased, prior to inheritance.

3. No at federal level, but most cantons levy such taxes.

Source: European Tax Handbook; national sources.

\section{Taxes on consumption could be better exploited}

Taxes on consumption are likely to be much less damaging to growth than taxes on labour, especially if they are broad based and operate on a destination principle, like VAT. In practice most OECD countries have kept their standard VAT rates constant for long periods of time and the OECD average has remained at just under 18\% for over a decade. However, the revenue effectiveness of the VAT also depends on the number of reduced rates and exemptions allowed. In that respect the $20 \%$ standard rate is significantly reduced in effective terms by the reduced rate of $10 \%$. Austria is also among the group of OECD countries which exempts new building from VAT. To the extent that Austria lags behind the most VAT-efficient OECD countries a review of the revenue effectiveness of the VAT would be warranted.

Figure 13. Efficiency of the VAT system

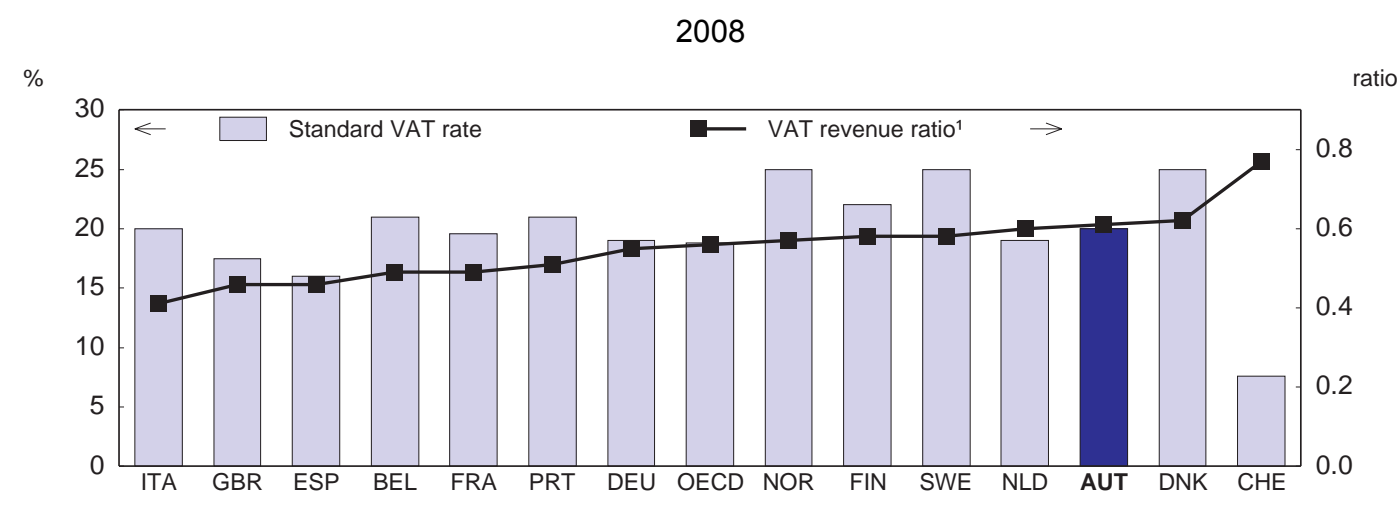

1. The VAT revenue ratio is defined as the ratio between VAT revenue and the theoretical revenue raised if the VAT was applied at the standard rate to total final consumption. VRR $=$ VAT Revenue/((Consumption $\times$ Standard VAT rate) - VAT Revenue) where Consumption corresponds to final consumption expenditure.

Source: OECD (2011), Consumption Tax Trends 2010. 


\section{Box 5. Fiscal policy recommendations}

\section{Develop a more forward-looking fiscal agenda}

- $\quad$ Achieve more upfront consolidation in the next few years to bring the debt-to-GDP ratio below $60 \%$ by 2020 . Medium- to long-term fiscal projections should be more instrumental in guiding front-loaded policy action.

- Increase transparency with regard to off-budget entities and contingent liabilities of the public sector. Evaluate the medium- and long-term fiscal impact of putting government programmes into off-budget vehicles.

\section{Strengthen the fiscal framework at all levels of government}

- $\quad$ Reinforce the current fiscal rule with a debt objective. In this context, specifying a target rate of growth of real general government spending would help.

- $\quad$ Reform the Domestic Stability Pact and the Fiscal Equalisation Act with a view to implementing the major elements of the federal budgetary reforms and avoiding pro-cyclical spending at sub-federal levels. The new sanctioning regime should be vigorously applied.

- Performance budgeting should be applied at all levels of government. Key policy objectives in the main public spending areas need to be defined, adequate performance indicators developed, and a clear procedure on how to use them in the concrete budgeting process has to be set out.

\section{Restrain public spending}

- $\quad$ Reduce public wage costs by replacing only a fraction of retiring government employees.

- $\quad$ Seek efficiency gains in all major public spending areas, notably in the education and health care sectors. Make full use of performance budgeting to this effect.

- $\quad$ Strengthen tendering processes in public procurement. Use Public-Private Partnerships when there is a genuine efficiency gain.

\section{Better target social and pension transfers}

- Eliminate all subsidised avenues into early retirement. Merge the special early retirement scheme in an actuarially neutral pension scheme. Eligibility criteria for disability pensions should be further tightened and the own-occupation based assessment of disability abolished if necessary.

- Fully harmonise the pension schemes of civil servants of states and municipalities and accelerate their incorporation into the general pension scheme.

- Increase the targeting of social transfers.

\section{Make the tax structure more employment and growth friendly}

- Rebalance the tax system with a view to increasing work incentives, encouraging investment and entrepreneurship, and reducing tax-induced distortions.

- $\quad$ Reinforce work incentives for low income workers by reducing social security contributions or introducing in-work benefits.

- Support women's full-time labour force participation by partly replacing monetary transfers to families with 
ECO/WKP(2011)66

in-kind spending on childcare facilities.

- Review the taxation of capital to make it less uneven. Valuations of real estate and land should be brought to market values and the reinstatement of inheritance and gift taxes considered.

- Improve tax administration efficiency by better integrating the collection of similar taxes. Increase the efficiency of the VAT system. 
ECO/WKP(2011)66

\section{BIBLIOGRAPHY}

Aiginger, K., H. Pitlik and M. Schratzenstaller (2010), "Options for the Consolidation of Public Budgets in Austria”, Austrian Economic Quarterly, No. 2/2010.

Albacete, N. and K. Wagner (2009), "Housing Finance of Austrian Households", Monetary Policy \& The Economy, Q3, Austrian National Bank, Vienna.

Arnold, J. (2008), "Do Tax Structures Affect Aggregate Economic Growth? Empirical Evidence From a Panel of OECD Countries“, OECD Economics Department Working Papers, No. 643.

Austrian Institute of Economic Research (WIFO) (2010), “Optionen zur Konsolidierung der öffentlichen Haushalte in Österreich", WIFO, Vienna.

Böheim, M., H. Handler and M. Schratzenstaller (2010), "Options for Revenue-based Fiscal Consolidation“, Austrian Economic Quarterly, No. 2/2010.

Bouis, R. and R. Duval (2011), "Raising Potential Growth After the Crisis: A Quantitative Assessment of the Potential Gains from Various Structural Reforms in the OECD Area and Beyond", OECD Economics Department Working Papers, No. 835.

Brandner, P., L. Diebalek and W. Köhler-Töglhofer (2009), "Budget balances decomposed: tracking fiscal policy in Austria", in Larch, M. and J. Nogueira Martins (eds.), Fiscal Policy Making in the European Union: An assessment of current practice and challenges, London, pp. 83-102.

Brunner, J.K. and C. Hoffmann (2010), „Versicherungsmathematisch korrekte Pensionsabschläge“, Soziale Sicherheit, No. 12/2010, Vienna.

Budimir, K. et al. (2010), "Erwerbsinaktivität und soziale Sicherungssysteme: Ein europäischer Vergleich", WIFO Monatsberichte, No. 12/2010.

Causa, O. (2009), "The Policy Determinants of Hours Worked Across OECD Countries", OECD Journal: Economic Studies, Vol. 2009.

Curristine, T., Z. Lonti and I. Joumard (2007), "Improving Public Sector Efficiency: Challenges and Opportunities", OECD Journal on Budgeting, Vol. 7, No. 1.

European Commission (2008), Public Finances in EMU - 2008, European Commission, Brussels.

European Commission (2009), The 2009 Ageing Report: Economic and Budgetary Projections for the EU-27 Member States (2008-2060), European Commission, Brussels.

Federal Ministry of Finance (2011b), Strategiebericht 2012-2015, BMF, Vienna. 
Federal Ministry of Finance (BMF) (2011a), Österreichisches Stabilitätsprogramm für die Jahre 2010 bis 2014, BMF, Vienna.

Federal Ministry of Labour, Social Affairs and Consumer Protection (BMASK) (2010), Sozialbericht 2009-2010, BMASK, Vienna.

Fuentes, A., E. Wurzel and A. Wörgötter (2006), "Reforming Federal Fiscal Relations in Austria", OECD Economics Department Working Papers, No. 474, OECD, Paris.

Gonand, F., I. Jourmard and R. Price (2007), "Public Spending Efficiency: Institutional Indicators in Primary and Secondary Education", OECD Economics Department Working Papers, No. 543, OECD, Paris.

Government Debt Committee (2010), Jahresbericht 2009, Government Debt Committee. Vienna.

Guger, A. and, /K. Knittler (2008), "Entwicklung und Verteilung der Einkommen”, in BMASK (ed.), Sozialbericht 2007-2008: Ressortaktivitäten und sozialpolitische Analysen, BMASK, Vienna.

Hauptverband der österreichischen Sozialversicherungsträger (HVB) (2010), Statistisches Handbuch der österreichischen Sozialversicherung 2010, HVB, Vienna.

Institute for Advanced Studies (IHS) (2010), Effizienzpotential in der Verwendung öffentlicher Mittel. Ein Überblick anhand einer Auswertung der Berichte des österreichischen Rechnungshofs, IHS, Vienna.

Johansson, A. et al. (2008), "Taxation and Economic Growth", OECD Economics Department Working Papers, No. 620.

Koen, V. and P. van den Noord (2005), "Fiscal Gimmickry in Europe: One-Off Measures and Creative Accounting", OECD Economics Department Working Papers, No. 417.

OECD (2005a), OECD Economic Surveys: Austria, Vol. 2005/8, OECD, Paris.

OECD (2005b), Ageing and employment policies: Austria, OECD, Paris.

OECD (2007a), Benefits and Wages 2007: OECD Indicators, OECD, Paris.

OECD (2007b), OECD Employment Outlook 2007, OECD, Paris.

OECD (2007c), OECD Economic Surveys: Austria, Vol. 2007/15, OECD, Paris

OECD (2009a), OECD Economic Surveys: Austria, Vol. 2009/10, OECD, Paris.

OECD (2009b), Going for Growth, OECD, Paris.

OECD (2010a), Tax Policy Reform and Economic Growth, OECD, Paris.

OECD (2010b), Taxing Wages 2009, OECD, Paris.

OECD(2010c), OECD Economic surveys: Germany, Vol. 2010/9, OECD, Paris.

OECD (2010d), OECD Economic Outlook, Vol. 2010/1, No. 88, OECD, Paris. 
OECD (2011), Pensions at a Glance 2011: Retirement-Income Systems in OECD and G20 Countries, OECD, Paris.

Pitlik, H., K. Budimir and N. Gruber (2010), "Options for Budget Consolidation on the Expenditure Side", Austrian Economic Quarterly, No. 2/2010.

Prammer, D. (2009), "Public Sector Outsourcing: Creative Accounting or a Sustainable Improvement? - A Case Study for Austria, Monetary Policy \& The Economy, Q1.

Reinhart, C.M. and K.S. Rogoff (2010), "Growing in a Time of Debt", American Economic Review, Vol. 100, No. 2.

Schratzenstaller, M. (2010), "Budgetkonsolidierung - allgemeine Überlegungen und Perspektiven für Österreich”, in Steger, G. (ed.), Öffentliche Haushalte in Österreich, Vienna, pp. 121-166.

Schratzenstaller, M. (2011), "Draft Federal Budget for 2011 Takes First Steps Towards Consolidation", Austrian Economic Quarterly, No. 1/2011.

Steger, G. (2010), "Austria's Budget Reform: How to Create Consensus for a Decisive Change of Fiscal Rules”, OECD Journal on Budgeting, Vol. 2010/No. 1.

Sutherland, D. et al. (2007), Performance Indicators for Public Spending Efficiency in Primary and Secondary Education, OECD Economics Department Working Papers, No. 546. 
ECO/WKP(2011)66

\section{WORKING PAPERS}

The full series of Economics Department Working Papers can be consulted at www.oecd.org/eco/workingpapers/

897. Austria: public sector inefficiencies have become less affordable

(October 2011) by Karin Fischer, Rauf Gönenç and Robert Price

896. Informality in Mexico

(September 2011) by Nicola Brandt

895. Reforming Austria's highly regarded but costly health system

(September 2011) by Rauf Gönenç, Maria. M. Hofmarcher, Andreas Wörgötter

894 Greener growth in the Belgian federation

(September 2011) by Tomasz Koźluk

893. Green growth and climate change policies in New Zealand

(September 2011) by Alexandra Bibbee

892. Has deregulation increased investment in infrastructure? Firm-level evidence from OECD countries

(September 2011) by Sónia Araújo

891. Ensuring a Sustainable and Efficient Fishery in Iceland

(September 2011) by Gunnar Haraldsson and David Carey

890. Japan's New Growth Strategy to create demand and Jobs

(September 2011) by Randall S. Jones and Byungseo Yoo

889. Labour market reforms in Japan to improve growth and equity

(September 2011) by Randall S. Jones and Satoshi Urasawa

888. Education reform in Japan

(September 2011) by Randall S. Jones

887. The Political Economy of Climate Change Mitigation Policies: How to Build a Constituency to Address Global Warming?

(August 2011) by Alain de Serres, John Llewellyn and Preston Llewellyn

886. Climate-Change Policy in the United Kingdom

(August 2011) by Alex Bowen and James Rydge

885. Improving Access and Quality in the Indian Education System

(August 2011) by Sam Hill and Thomas Chalaux

884. How Institutions Shape the Distributive Impact of Macroeconomic Shocks: A DSGE Analysis (July 2011) by Rudiger Ahrend, Charlotte Moeser and Tommaso Monacelli

883. Can India Achieve Double-Digit Growth?

(July 2011) by Richard Herd, Paul Conway, Sam Hill, Vincent Koen and Thomas Chalaux 
882. Predicting peaks and troughs in real house prices

(July 2011) by Linda Rousová and Paul van den Noord

881. Public sector spending efficiency in Estonia: healthcare and local government (July 2011) by Zuzana Smidova

880. How to move Product Market Regulation in New Zealand back towards the frontier (July 2011) by Paul Conway

879. Financial sector reform in India: time for a second wave?

(July 2011) by Richard Herd, Vincent Koen, Ila Paitnak and Ajay Shah

878. Policies to rebalance housing markets in New Zealand

(July 2011) by Calista Cheung

877. The sharing of macroeconomic risk: Who loses (and gains) from macroeconomic shocks (July 2011) Rudiger Ahrend, Jens Arnold and Charlotte Moeser

876. Estonia: making the most of globalisation

(June 2011) Robert Price and Andreas Wörgötter

875. The effects of downturns on labour force participation: evidence and causes (June 2011) Romain Duval, Mehmet Eris and Davide Furceri

874 A dynamic factor model for world trade growth

(June 2011) Stéphanie Guichard and Elena Rusticelli

873. Towards a better understanding of the informal economy

(May 2011) Dan Andrews, Aida Caldera Sánchez and Åsa Johansson

872. Tax competition between sub-central governments

(May 2011) Hansjörg Blöchliger and José-Maria Pinero-Campos

871. The growth effects of current account reversals: the role of macroeconomic policies

(May 2011) Luiz de Mello, Pier Carlo Padoan and Linda Rousová

870. Les politiques du logement en France

(May 2011) Bénédicte Rolland

869. How important is wealth for explaining household consumption over the recent crisis? An empirical study for the United States, Japan and the euro area

(May 2011) Clovis Kerdrain

868. Adjusting fiscal balances for asset price cycles

(May 2011) Robert Price and Thai-Thanh Dang

867. Improving the functioning of the housing market in the United Kingdom

(May 2011) Christophe André

866. An analysis of demand for foreign exchange reserves

(May 2011) Peter Vujanovic 